\title{
¿Data-Driven Analysis of Climate Change in Saudi Arabia: Trends in Temperature Extremes and Human Comfort Indicators $\mathcal{O}$
}

\author{
NATAlia OdNOLETKOVA ${ }^{\mathrm{a}}$ AND TADEUSZ W. PATZEK ${ }^{\mathrm{a}}$ \\ a Ali I. Naimi Petroleum Engineering Research Center, King Abdullah University of Science and Technology, Thuwal, Saudi Arabia
}

(Manuscript received 4 December 2020, in final form 24 May 2021)

\begin{abstract}
We have analyzed the long-term temperature trends and extreme temperature events in Saudi Arabia between 1979 and 2019. Our study relies on high-resolution, consistent, and complete ERA5 reanalysis data from the European Centre for Medium-Range Weather Forecasts (ECMWF). We evaluated linear trends in several climate descriptors, including temperature, dewpoint temperature, thermal comfort, and extreme event indices. Previous works on this topic used data from weather station observations over limited time intervals and did not include temperature data for recent years. The years 2010-19 have been the warmest decade ever observed by instrumental temperature monitoring and are the eight warmest years on record. Therefore, the earlier results may be incomplete, and their results may no longer be relevant. Our findings indicate that, over the past four decades, Saudi Arabia has warmed up at a rate that is $50 \%$ higher than the rest of the landmass in the Northern Hemisphere. Moreover, moisture content of the air has significantly increased in the region. The increases of temperature and humidity have resulted in the soaring of dewpoint temperature and thermal discomfort across the country. These increases are more substantial during summers, which are already very hot relative to winters. Such changes may be dangerous to people over vast areas of the country. If the current trend persists into the future, human survival in the region will be impossible without continuous access to air conditioning.
\end{abstract}

KEYWORDS: Atmosphere; Land surface; Climate change; Reanalysis data; Adaptation; Emergency preparedness; Planning; Societal impacts

\section{Introduction}

Global temperatures have been steadily increasing since the beginning of widespread instrumental temperature monitoring in the late nineteenth century (IPCC 2013). Temperature changes over land are greater than those over oceans, and land surface in the Northern Hemisphere is warming faster than the Southern Hemisphere. Since the late 1970s, the warming rate has accelerated, and land surface temperature in the Northern Hemisphere has increased by almost $1.5^{\circ} \mathrm{C}$ (Fig. 1). Land warming varies across the continents and countries (see section 1 in the online supplemental material for the global map of historical temperature change). Saudi Arabia is the global hot spot of temperature increase and is experiencing one of the fastest warming rates on the planet. Between 1979 and 2019, the mean temperature in the kingdom increased by $2.1^{\circ} \mathrm{C}$, almost 3 times the global average (see section 3 and Fig. 5a of the online supplemental material). Summers warm faster, and average JuneAugust temperatures have risen by $2.5^{\circ} \mathrm{C}$ over the same time.

While Saudi Arabia already has a very hot climate, studies predict that the kingdom will continue to experience significant

๑ Denotes content that is immediately available upon publication as open access.

Supplemental information related to this paper is available at the Journals Online website: https://doi.org/10.1175/JAMC-D-200273.s1.

Corresponding author: Tadeusz W. Patzek, tadeusz.patzek@ kaust.edu.sa warming trends in the future decades, and extreme weather events are likely to become more frequent (Driouech et al. 2020; Almazroui et al. 2017). The strongest temperature increases in the future will continue to persist during summer, when it is warm already, and not during winter, which is more typical of other parts of the planet (Lelieveld et al. 2016). According to the IPCC Fifth Assessment Report (Collins et al. 2013), in a high emission scenario RCP8.5 by the end of the century (in 2081-2100) the temperature increase over Saudi Arabia is expected to be between $5^{\circ}$ and $7^{\circ} \mathrm{C}$ above that in 1986-2005, or about $0.5^{\circ}-0.7^{\circ} \mathrm{C}$ in a decade. Almazroui (2013) predicts for Saudi Arabia the trend of $0.65^{\circ} \mathrm{C} \mathrm{decade}^{-1}$ during the years 2021-70, which surpasses the 1979-2019 warming trend of $0.52^{\circ} \mathrm{C}$ decade $^{-1}$ (Fig. 2). For precipitation, El-Samra et al. (2017) shows evidence of a significantly drier climate over the northeast Arabian Peninsula from 2016 until the midcentury. However, by the midcentury and by the end of the century, precipitation is projected to increase relative to the present climate (Almazroui et al. 2017) over most parts of the peninsula.

Climate change will severely affect the kingdom's economy and make the population vulnerable to extreme weather. Kompas et al. (2018) estimated that the $3^{\circ} \mathrm{C}$ global warming will lead to $1.3 \% \mathrm{yr}^{-1}$ decrease in Saudi Arabia's gross domestic product (GDP) by midcentury and $5.4 \% \mathrm{yr}^{-1}$ in the long run. Today, per capita electricity consumption in Saudi Arabia is already among the highest in the world, with air conditioning making up a record high $70 \%$ of household consumption (Lapillonne 2019; Enerdata 2020). Rising temperatures will further increase demand for electrical power. Each $1^{\circ} \mathrm{C}$ of temperature increase in Saudi Arabia is associated with nearly $2.5 \%-4 \%$ increase in power generation in different 
(a)

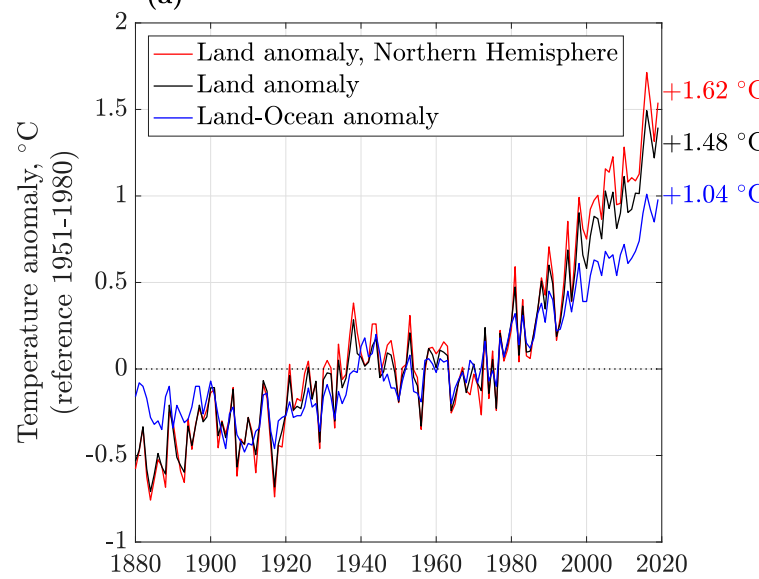

(b)

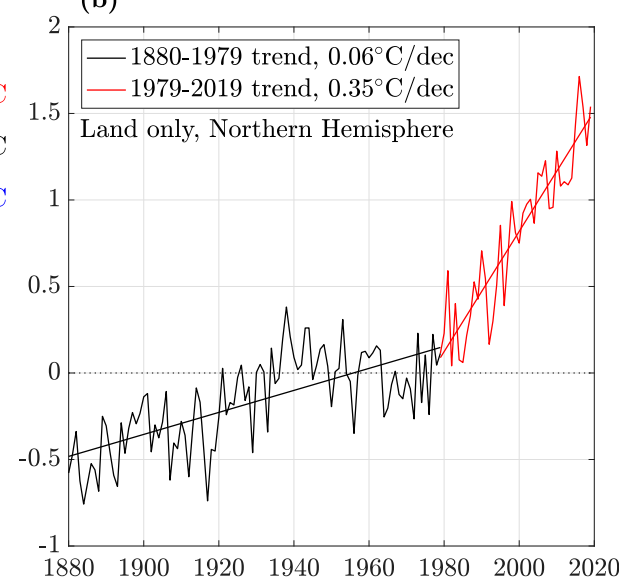

FIG. 1. Global annual mean temperature anomalies from NASA GISS (GISTEMP Team 2020a,b; Lenssen et al. 2019). (a) The combined land surface air and sea surface temperature anomalies (blue) and land surface air temperature anomalies only (black for both hemispheres and red for the Northern Hemisphere only). The temperature changes between 1880 and 1979 are based on a linear trend. (b) The land surface air temperature anomalies for the Northern Hemisphere with the linear regression fit.

regions of the country (Howarth et al. 2020). In agriculture, temperature increase impacts the demand for freshwater, a scarce resource in Saudi Arabia. It also changes thermal limits of crops and decreases yields (Tarawneh and Chowdhury 2018; Parry 1993). There are numerous studies of the effects of climate change and extreme temperature events on mortality rates and cardiovascular, respiratory, and rodent-borne diseases (Patz et al. 2005; Thow and De Blois 2008). For example, the rise of all-cause mortality is about $20 \%-30 \%$ when ambient temperatures exceed $40^{\circ} \mathrm{C}$ (Agarwal et al. 2018). An increase of ambient temperatures would cause an increase in geographical distribution of some vector organisms (e.g., malarial mosquitoes) and transmission of numerous vector-borne diseases such as malaria and dengue fever (McMichael et al. 2003; Epstein 1999). The total duration of heat waves in a year

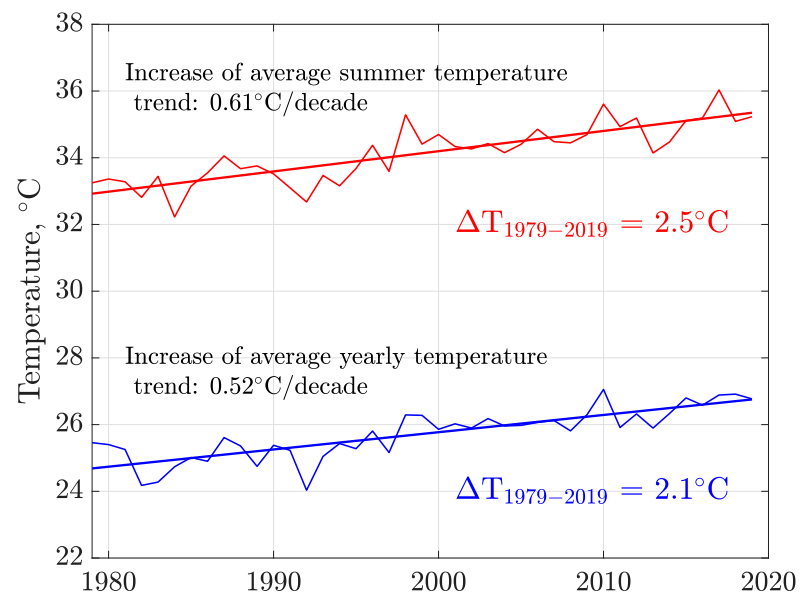

FIG. 2. Temperature trends across Saudi Arabia based on a linear regression model for the 1979-2019 period. Summer months are June, July, and August. (prolonged periods of maximum temperature records) is growing exponentially in most of the big cities in Saudi Arabia. These waves are the most significant weather-related cause of mortality in the world (Gasparrini and Armstrong 2011; Gronlund et al. 2018). As for minimum temperatures, nights are warming far more rapidly than days in Saudi Arabia. This increase of daily minimum rather than maximum temperatures is far from innocuous. The night is a time to release thermal stress accumulated during the day, which is important for people, as well as animals and ecosystems. Warmer nights mean buildings and their occupants do not have much chance to cool down. This situation is exacerbated in the cities, where concrete and asphalt accumulate heat during the day and release it at night. This accumulation increases the demand for air conditioning during the night and early morning time, raising the need to increase baseload power production.

Even though temperature is the key parameter used to assess climate evolution, the broad impact of climate change is not solely limited to the effects of temperature increase. Therefore, we also examine trends in human comfort indices, which serve as impact-oriented indicators of climate change: the heat index (HI) and the universal thermal comfort index (UTCI). In addition, we have studied changes in dewpoint temperature at which the air can no longer "hold" all of the water vapor that is mixed with it, and some of the water vapor must condense into liquid water. Dewpoint has a direct impact on heating, ventilation, and air conditioning of buildings, power generation and agriculture. As functions of temperature, these parameters experienced significant changes during the past decades. Examples of relevant studies that assess the global exposure to heat-humidity extremes include $\mathrm{Li}$ et al. (2020), Zhang et al. (2021).

There are comprehensive studies of the Arabian Peninsula climate and its sensitivity to the various climate drivers, such as ocean temperature oscillations (Predybaylo et al. 2017), 
monsoons (Raj et al. 2019), dust (Osipov and Stenchikov 2018; Bangalath and Stenchikov 2015), and volcanic perturbations (Osipov and Stenchikov 2017; Dogar et al. 2017). However, the overarching studies on the topic of temperature trends in Saudi Arabia built on high-quality data are limited. Some of the previous publications focused on temperature changes in specific cities or regions of Saudi Arabia only (Rehman and AlHadhrami 2012; Tarawneh and Chowdhury 2018). The studies that analyzed changes at the country level relied on the data from weather stations (ElNesr et al. 2010; Almazroui et al. 2014; AlSarmi and Washington 2011). Additionally, previous studies mostly relied on weather data prior to 2010, with the exception of only a couple of publications that incorporate recent years in the analysis (Almazroui 2020a,b). The last decade (2010-19) includes the eight warmest years ever observed by instrumental temperature monitoring. Therefore, the inclusion of this period serves to quantify the most abrupt climate change trends.

The goal of this study is to analyze the high-quality hourly data from the most recent reanalysis of global climate from the European Centre for Medium-Range Weather Forecasts (ECMWF ERA5) for the past 41 years (1979-2019) to capture the mean annual and seasonal trends in temperature and temperature-related indices. In particular, we aim to study how dewpoint temperature, heat index, and universal thermal comfort index have changed over the past four decades. To the best of our knowledge, the study of historic changes in these human comfort parameters has not been done for Saudi Arabia yet. The results are shown as maps to reveal countryscale changes and as a summary table with the detailed statistics for key cities. The benefit of using the ERA5 is that this dataset is publicly available, which is particularly important for Saudi Arabia, where access to data from weather stations is limited. ERA5 near-surface temperature and dewpoint temperature data correlate well with weather station observations globally ( $\mathrm{Li}$ et al. 2020; section 3 of the online supplemental material) and over key cities in Saudi Arabia (section 2 in the online supplemental material). Furthermore, our reanalysis allows investigations of climate changes in the locations where instrumental temperature records have been insufficient or absent. The Red Sea Project and "NEOM" (from Neo Mustaqbal, or New Future) serve as examples of such areas.

\section{Materials and methods}

\section{a. Description of the dataset}

The main source of atmospheric data for the present study is the Copernicus Climate Change Service (2020b). Their opensource dataset provides hourly data for many atmospheric, land surface, and sea-state parameters. In this study, we have obtained the hourly 2-m temperature, dewpoint temperature, and universal thermal comfort index data for the entire period of 1979-2019. ERA5 is the latest, fifth generation of the ECMWF atmospheric reanalysis of global climate. This reanalysis "combines model data with observations from across the world into a globally complete and consistent dataset using the laws of physics" (Hersbach 2017). Atmospheric data are provided on a regular latitude-longitude grid at $0.25^{\circ} \times 0.25^{\circ}$ resolution. These data can be visualized as a continuous tiled surface, and the data values can be referred to as centroids of the tiles (Hennermann 2020). For the temperature estimation over cities, we selected the value from the ERA5 grid box encompassing the city coordinates, see Table 1 . As each data value represents a grid cell with size $0.25^{\circ} \times 0.25^{\circ}$, it is important to note that this areal averaging can mask the local temperature spikes. The average trends over Saudi Arabia (Fig. 2) are obtained as a weighted average of the data from grid cells that fall within its borders. The ERA5 temperatures and dewpoint temperatures are reasonably close to weather station observations over Saudi Arabia (section 2 of the online supplemental material).

To access global historic temperature trends over a longer time span, we have accessed National Aeronautics and Space Administration Goddard Institute for Space Studies (NASA GISS) datasets (GISTEMP Team 2020a,b; Lenssen et al. 2019). These sets allow us to compare global and regional trends in temperature for the recent period (1979-2019) with historic ones (starting 1880). Average global values obtained from the NASA GISS data correlate well with ERA5 across the period of 1979-2019, as discussed in section 3 of the online supplemental material.

\section{b. Climate change indicators}

The objective of this study is to analyze only the temperaturerelated indices. In addition to temperature, dewpoint temperature, heat index, and universal thermal comfort index, we have studied changes in various temperature extreme indices based on the Expert Team on Climate Change Detection and Indices classification (ETCCDI 2020; climdex.org 2020; Karl et al. 1999; Peterson et al. 2001; Peterson 2005). These temperature extremes indicators are used very commonly in climate change trends analytics. Examples of relevant studies include Ntoumos et al. (2020), Almazroui et al. (2014), You et al. (2008), Huang et al. (2010), Alexander and Arblaster (2017).

A summary of the examined parameters along with their definitions is shown in Table 3 of section 7 in the online supplemental material. For the percentile-based indicators (warm days and nights, cold days and nights, warm and cold spell duration index), the 1979-2009 base period was used. This period was also used by NASA Goddard Space Flight Center (2020). However, different studies calculate climate change indices based on different baseline periods. For example, ETCCDI suggests using the 1961-90 time frame as a base. Therefore, one needs to be careful when comparing results of the same indicators obtained with different methods.

\section{c. Human thermal comfort indicators}

As Earth is warming, and exposure of people to extreme weather events becomes more frequent, the estimation of the effect of weather on public health is gaining significant attention. Environmental health studies often use "heat index" to measure exposure to heat. This index is measured in degrees Celsius or Fahrenheit and is a function of both temperature and humidity. Numerous ways to calculate heat index 
TABLE 1. Summary table with the ERA5 pinpoint coordinates of main cities and historic maximum and minimum temperatures observed during the 1979-2019 period. Data source: ERA5.

\begin{tabular}{|c|c|c|c|c|c|c|}
\hline No. & City & Coordinates & $T_{\max }\left({ }^{\circ} \mathrm{C}\right)$ & Date & $T_{\min },\left({ }^{\circ} \mathrm{C}\right)$ & Date \\
\hline 1 & Abha & $18.25^{\circ} \mathrm{N}, 42.50^{\circ} \mathrm{E}$ & 34.9 & 21 Jun 2010 & 4.2 & 7 Feb 1993 \\
\hline 2 & Arar & $31.00^{\circ} \mathrm{N}, 41.00^{\circ} \mathrm{E}$ & 47.0 & 13 Jul 2010 & -7.0 & 16 Jan 2008 \\
\hline 3 & Al Bahah & $20.00^{\circ} \mathrm{N}, 41.50^{\circ} \mathrm{E}$ & 42.6 & 14 Aug 2015 & 2.9 & 06 Feb 1993 \\
\hline 4 & Buraiydah & $26.25^{\circ} \mathrm{N}, 44.00^{\circ} \mathrm{E}$ & 47.2 & 10 Aug 2001 & -5.2 & 16 Jan 2008 \\
\hline 5 & Ad Dammām & $26.50^{\circ} \mathrm{N}, 50.00^{\circ} \mathrm{E}$ & 45.8 & $15 \mathrm{Jul} 2000$ & 4.9 & 16 Jan 2008 \\
\hline 6 & Dhahran & $26.25^{\circ} \mathrm{N}, 50.00^{\circ} \mathrm{E}$ & 48.0 & 10 Aug 2009 & 0.6 & 8 Jan 1992 \\
\hline 7 & Hafar Al-Batin & $28.25^{\circ} \mathrm{N}, 46.00^{\circ} \mathrm{E}$ & 48.9 & 13 Jun 2017 & -3.6 & 17 Jan 2008 \\
\hline 8 & Hā'il & $27.50^{\circ} \mathrm{N}, 41.75^{\circ} \mathrm{E}$ & 44.9 & 1 Aug 2017 & -7.3 & 17 Jan 2008 \\
\hline 9 & Jidda & $21.50^{\circ} \mathrm{N}, 39.25^{\circ} \mathrm{E}$ & 44.1 & 1 Aug 2013 & 14.1 & 14 Jan 1992 \\
\hline 10 & Jizan & $17.00^{\circ} \mathrm{N}, 42.75^{\circ} \mathrm{E}$ & 45.5 & 18 Jun 2016 & 14.8 & 7 Feb 1993 \\
\hline 11 & Khamīs Mushayt & $18.25^{\circ} \mathrm{N}, 42.75^{\circ} \mathrm{E}$ & 34.0 & 25 Jul 2019 & 1.4 & 7 Feb 1993 \\
\hline 12 & Mecca & $21.50^{\circ} \mathrm{N}, 39.75^{\circ} \mathrm{E}$ & 50.0 & $30 \mathrm{Jul} 2017$ & 9.1 & 6 Feb 1992 \\
\hline 13 & Medina & $24.50^{\circ} \mathrm{N}, 39.50^{\circ} \mathrm{E}$ & 46.9 & 9 Aug 2001 & 2.6 & 13 Jan 1992 \\
\hline 14 & Najran & $17.50^{\circ} \mathrm{N}, 44.25^{\circ} \mathrm{E}$ & 40.5 & 17 Aug 2016 & -1.1 & 1 Jan 2005 \\
\hline 15 & NEOM & $28.25^{\circ} \mathrm{N}, 35.00^{\circ} \mathrm{E}$ & 46.5 & 4 Jul 1996 & 0.9 & 15 Jan 2008 \\
\hline 16 & Riyadh & $24.75^{\circ} \mathrm{N}, 46.75^{\circ} \mathrm{E}$ & 47.1 & $31 \mathrm{Jul} 2007$ & -4.0 & 17 Jan 2008 \\
\hline 17 & Sakākah & $30.00^{\circ} \mathrm{N}, 40.25^{\circ} \mathrm{E}$ & 47.1 & 13 Jul 2010 & -6.1 & 5 Jan 1992 \\
\hline 18 & Tabuk & $28.25^{\circ} \mathrm{N}, 37.00^{\circ} \mathrm{E}$ & 44.6 & $11 \mathrm{Jul} 2010$ & -4.5 & 6 Jan 1989 \\
\hline 19 & Taif & $21.25^{\circ} \mathrm{N}, 40.50^{\circ} \mathrm{E}$ & 39.0 & 23 Jul 2016 & 1.0 & 6 Feb 1993 \\
\hline 20 & The Red Sea Project & $25.75^{\circ} \mathrm{N}, 37.00^{\circ} \mathrm{E}$ & 47.9 & 20 Aug 2015 & 7.3 & 6 Jan 1983 \\
\hline
\end{tabular}

are found in literature. Anderson et al. (2013) examined 21 separate methods of heat index calculations found in the publications on the subject. The authors examined 1) how consistent the results produced by the examined algorithms are with theoretical concepts of apparent temperature, and 2) whether different methods of heat index estimation generate similar output. Building on the work of Anderson et al. (2013), we chose three different methods to calculate heat index. These methods are among the best in terms of consistency of their results with the original Steadman's concept of apparent temperature (Steadman 1979a,b, 1984).

The first method is the U.S. National Weather Service algorithm from the National Oceanic and Atmospheric Administration (NOAA NWS 2020a), which is described in section 5 of the online supplemental material. The procedure for the second method (Schoen 2005) is defined according to

$$
\mathrm{HI}_{C}=T_{C}-1.0799 e^{0.03755 T_{C}}\left[1-e^{0.0801\left(D_{C}-14\right)}\right],
$$

where $\mathrm{HI}_{\mathrm{C}}$ is the heat index $\left({ }^{\circ} \mathrm{C}\right), T_{C}$ is the air temperature $\left({ }^{\circ} \mathrm{C}\right)$, and $D_{C}$ is the dewpoint temperature $\left({ }^{\circ} \mathrm{C}\right)$. The third method $(\mathrm{El}$ Morjani et al. 2007; Oka 2011) is defined according to

$$
\begin{aligned}
\mathrm{HI}_{F}= & -42.379+2.04901523 T_{F}+10.14333127 H \\
& -0.22475541 T_{F} H-\left(6.83783 \times 10^{-3}\right) T_{F}^{2} \\
& -\left(5.481717 \times 10^{-2}\right) H^{2}+\left(1.22874 \times 10^{-3}\right) T_{F}^{2} H \\
& +\left(8.5282 \times 10^{-4}\right) T_{F} H^{2}-\left(1.99 \times 10^{-6}\right) T_{F}^{2} H^{2}
\end{aligned}
$$

where $\mathrm{HI}_{F}$ is the heat index $\left({ }^{\circ} \mathrm{F}\right), T_{F}$ is the air temperature $\left({ }^{\circ} \mathrm{F}\right)$, and $H$ is the relative humidity (\%). Note that, instead of Eq. (2), the correction factor is $\mathrm{HI}_{F}=T_{F}$ when $T_{F} \leq 78.8^{\circ} \mathrm{F}$ or $H \leq 39 \%$. Equation (2) with slight modifications of a correction factor is often found in other publications on the topic
(Fandoeva et al. 2009; Di Cristo et al. 2007; Rajib et al. 2011; Johnson and Long 2005).

We use the NWS algorithm as a primary method to evaluate heat index. In section 4 of the online supplemental material, we show how results obtained using the three methods of $\mathrm{HI}$ calculation differ from each other and how they correlate with actual temperature and universal thermal comfort index, which was also investigated. UTCI is defined as "the air temperature of a reference outdoor environment that would elicit in the human body the same physiological response (sweat production; shivering; skin wittedness; ${ }^{1}$ skin blood flow; and rectal, mean skin, and face temperatures) as the actual environment." This index was introduced in 2009 by the European Cooperation in Science and Technology (COST) Action 730, and since then it has been often referred to as a state-of-theart thermal comfort parameter. UTCI is a function of air temperature, humidity, wind speed, and radiation (ECMWF 2020; Di Napoli et al. 2020; Jendritzky et al. 2012). The UTCI dataset was obtained from ERA5.

\section{d. Statistical methods for trend analysis}

We use a linear model to test the trend of temperature and other climate indices changes (described in Table 3 in section 7 of the online supplemental material). Publications on the subject commonly report warming trends as degrees Celsius per decade, century, or year based on a linear model. We use ordinary linear regression with annual mean or summer mean values of an index as a dependent variable. The results are produced using the built-in function "fitlm" in the MATLAB

\footnotetext{
${ }^{1}$ By definition, skin wettedness is the fraction of the total surface area of the skin covered with sweat.
} 
(a)

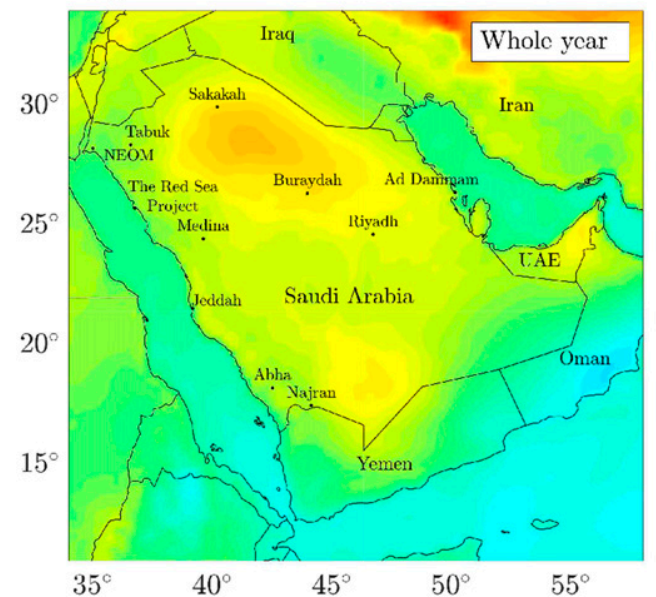

(b)

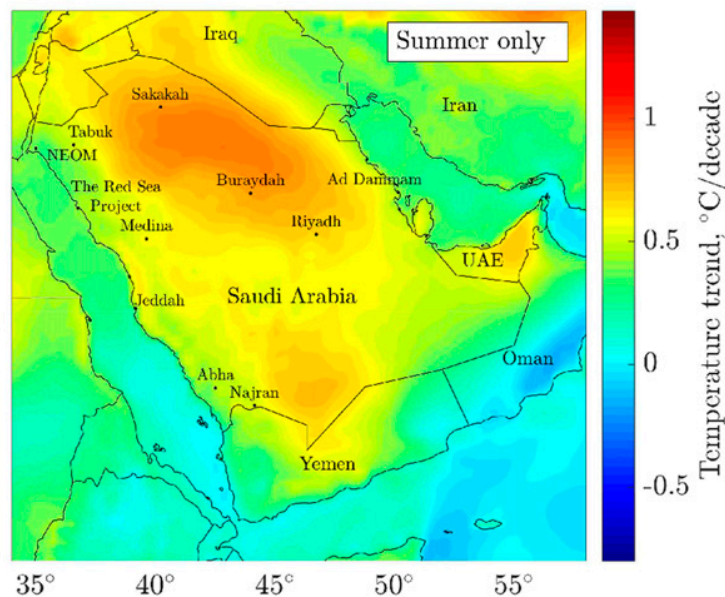

FIG. 3. Linear trends in (a) annual and (b) summer mean temperature across Saudi Arabia and surrounding regions for the 1979-2019 period. Vertical axis: latitude; horizontal axis: longitude.

proprietary software. We test the obtained value of regression coefficient $\hat{\beta}$, the trend, for statistical significance with the confidence levels of $95 \%$ and $99 \%$. The null hypothesis suggests there is no significant trend, that is, $H_{0}: \beta_{1}=0$. The alternative hypothesis suggests that the regression coefficient is significantly different from zero, that is, $H_{1}: \beta_{1} \neq 0$. This means that the trend is statistically significant, and the slope is noticeably positive $(\hat{\beta}>0)$ or negative $(\hat{\beta}<0)$.

\section{Results and discussion}

\section{a. Temperature and temperature extremes}

The last decade in Saudi Arabia has been rich in extreme maximum temperature events. Table 1 provides a summary of historic maximum and minimum temperatures for key cities in Saudi Arabia during the 1979-2019 period. In contrast, record low temperatures occurred many years ago. More than onehalf of the cities presented in the analysis experienced minimum temperature records during the winters of 1992 and 1993, attributed to the global cooling effect of the Mount Pinatubo eruption in 1991 (see Fig. 5a in section 3 of the online supplemental material) (Osipov and Stenchikov 2017; Dogar et al. 2017). A third of the locations had record minimum temperatures in January 2008, caused by El Niño-Southern Oscillation (ENSO) (NOAA NCEI 2020). Since 2008, there have been no minimum temperature records in the studied cities.

While average annual temperature across Saudi Arabia has been increasing steadily by $0.5^{\circ} \mathrm{C}$ decade $^{-1}$ (Fig. 2), the warming has not been even across the kingdom's territory. Coastal locations are less sensitive to climate change as, for example, Jidda, $90 \mathrm{~km}$ south of the King Abdullah University of Science and Technology (KAUST) campus. Cities on the Persian Gulf coast (e.g., Ad Dammām) are warming slightly faster than the locations next to the Red Sea. The northern regions are subject to the higher rates of warming than the rest of the country; see the spatial map of warming trends in Fig. 3. These northern regions are Al Jawf, Hā'il, Qassim, and the northern borders, with the capital cities, Sakākah, Hā'il, Buraydah, and Arar, respectively. Furthermore, the rate of mean summer temperature increase is different from that of winter. In all studied major cities in Saudi Arabia, summers warm faster than the mean annual temperature, or at least at the same rate (Table 4 in section 7 of the online supplemental material). For example, Sakākah and Hā'il summers became warmer on average by $3^{\circ} \mathrm{C}$ since 1979 . The planned city of the future NEOM is an exception, with summer temperatures increasing more slowly than the year-round ones.

We have also calculated temperature changes for each month of the year. These results are presented in section 8 of the supplemental material for three locations: the most populated Riyadh and Jidda, and NEOM, the largest gigaproject in Saudi Arabia. All months in these cities have positive temperature changes, although they are not always statistically significant. Negative trends are never observed. In Riyadh, greater changes occurred in June-September, as well as in February and March. The temperature increase for these months has been more than $2.6^{\circ} \mathrm{C}$ over the past 41 years. The statistically significant trends with the lowest $p$ values are observed in June-September. The trend is not significant in November and December at the $95 \%$ confidence level. Jidda and NEOM warm at a slower rate. The Red Sea plays an important role for coastal locations, contributing to a milder climate and delaying the effects of climate change. The highest rate of temperature increase in Jidda is in February $\left(2.3^{\circ} \mathrm{C}\right)$ and May-August $\left(1.6^{\circ}-1.7^{\circ} \mathrm{C}\right)$, with June-August having the most statistically significant trends. In NEOM, the rate warming has remained low, although weak warming trends are observed in nonsummer months.

Extreme temperature indicators allow us to have an indepth view of how climate has been changing over the past decades. While mean annual or seasonal temperature trend analysis gives a good overview of the issue, it often masks extreme weather patterns. For example, in Saudi Arabia there is a drastic increase in daily minimum temperatures across a substantial part of the kingdom, while daily maximum 
(a)

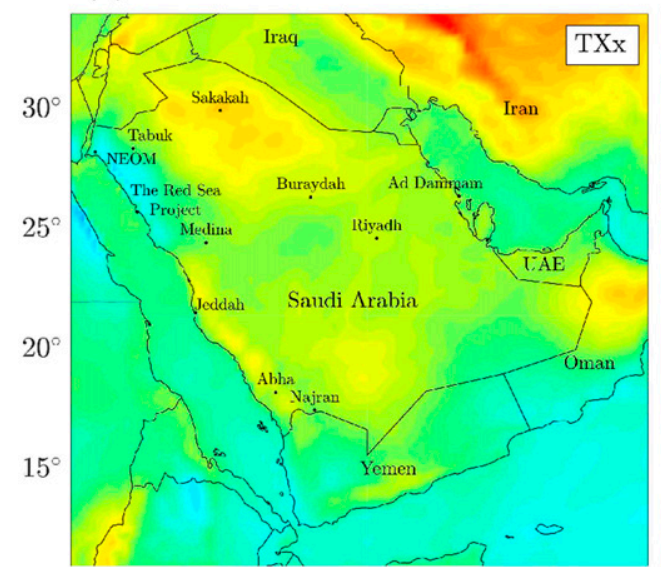

(c)

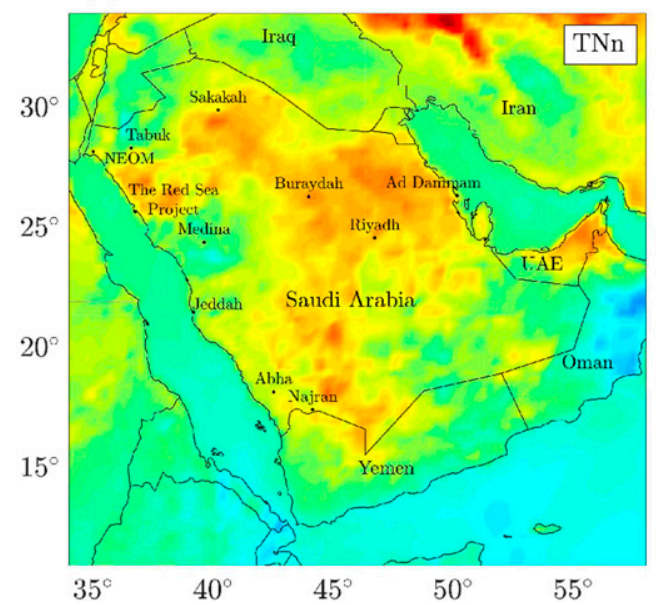

(b)

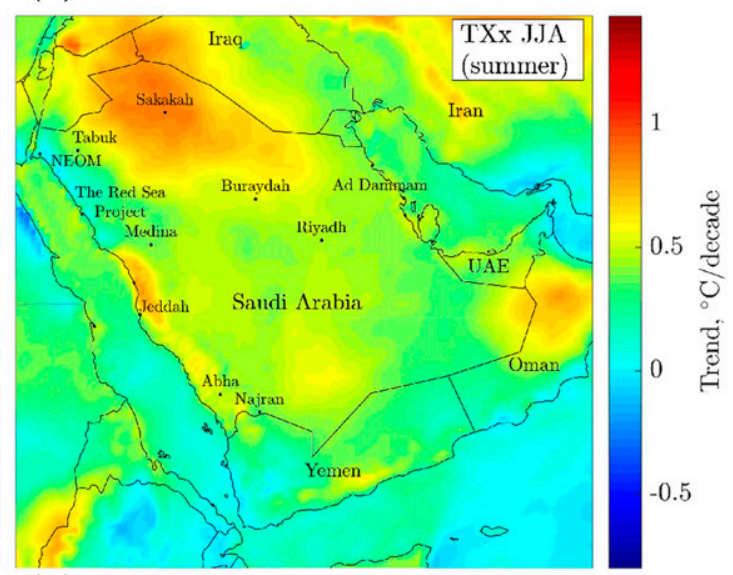

(d)

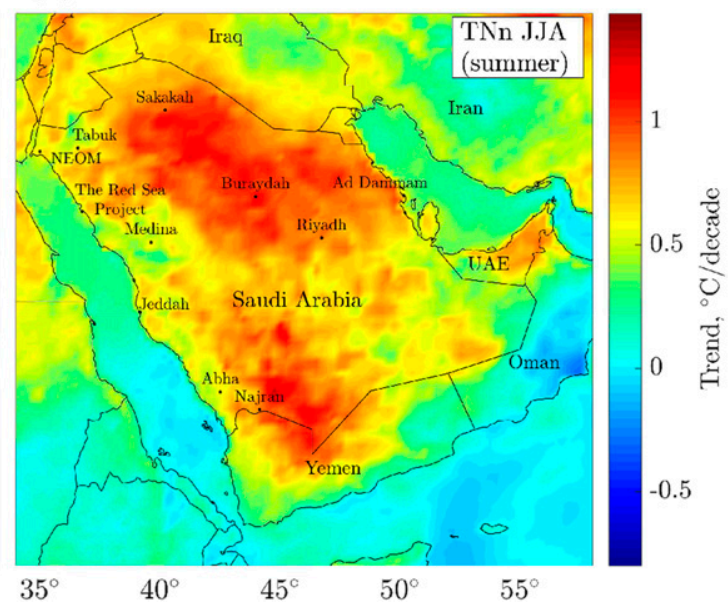

FIG. 4. Linear trends in (top) monthly maximum of daily maximum (TXx) and (bottom) monthly minimum of daily minimum (TNn) temperature change for (a),(c) the whole year and (b),(d) summer only. Study period: 1979-2019.

temperatures are increasing at a slower pace, and a map of the mean temperature change trends conceals this fact (Fig. 3). This observation agrees with a global trend: since the latter half of the twentieth century, nights have been warming faster than days on average across the surface of the planet, leading to a significant decrease of the diurnal temperature range (DTR) (Thorne et al. 2016; Vose et al. 2005). In Saudi Arabia, these changes are amplified during summer (Figs. 4 and 5).

The increase of average summer monthly minimum (TNn) has been about $4^{\circ} \mathrm{C}$ since the late 1970s for several Saudi Arabia regions, represented here by Buraydah, Hafar Al-Batin, and Hā'il cities. Among the few areas less affected by increasing monthly minimum temperatures are the surroundings of Tabuk

\footnotetext{
${ }^{2}$ The Asir Mountains are located in southwestern Saudi Arabia and run parallel to the Red Sea. Empty Quarter, or the Rub' alKhali, is a giant sand desert that encompasses most of the southeastern third of the Arabian Peninsula. The desert territory in Saudi Arabia constitutes a wide area that stretches parallel to the borders with Yemen and Oman.
}

and Medina, some of the Red Sea coastal areas, Asir Mountains, and the eastern part of Empty Quarter (Fig. 4). ${ }^{2}$

Monthly maximum (TXx) is increasing rapidly in the north of Saudi Arabia and regions along the central and southern part of the Red Sea, between the coast and the mountains. There is also an area in the kingdom where daily maximum temperatures essentially do not change. It is the western locations along the Red Sea north coast. If this trend continues into the future, it will put NEOM at a favorable and strategically important position from the climate change adaptation point of view.

The monthly minimum of daily maximum $(\mathrm{TNx})$ parameter represents cold days, and the monthly maximum of daily minimum (TXn) represents warm nights; see Fig. 5. The trend in $\mathrm{TNx}$ is similar with the trend in monthly maximum of daily maximum ( $\mathrm{TXx}$ ), and the trend in TXn is similar to the trend in monthly minimum of daily minimum (TNn) (Fig. 4). This is because TNx and TXx represent daytime extremes (cold and warm days), whereas TXn and TNn represent nighttime extremes (warm and cold nights). The daily minimum temperatures increased significantly across the Persian Gulf coast but not along the Red Sea (cold nights became warmer). The 
(a)

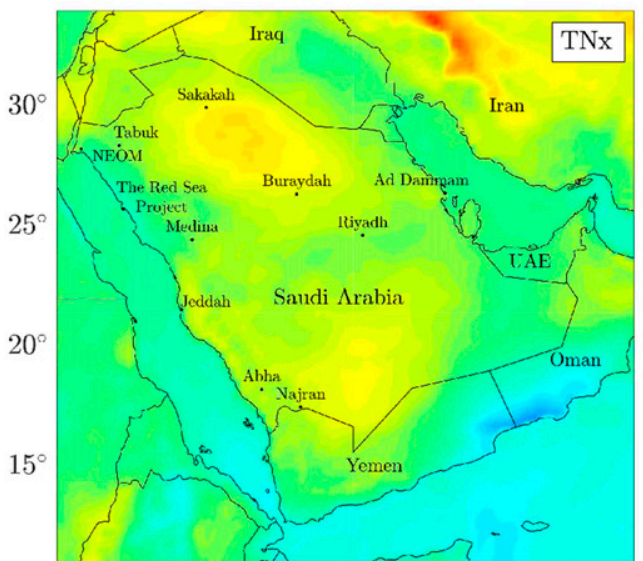

(c)

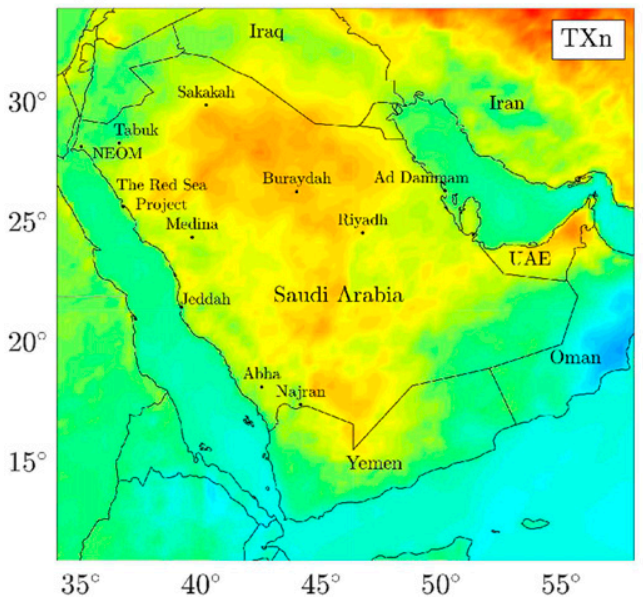

(b)

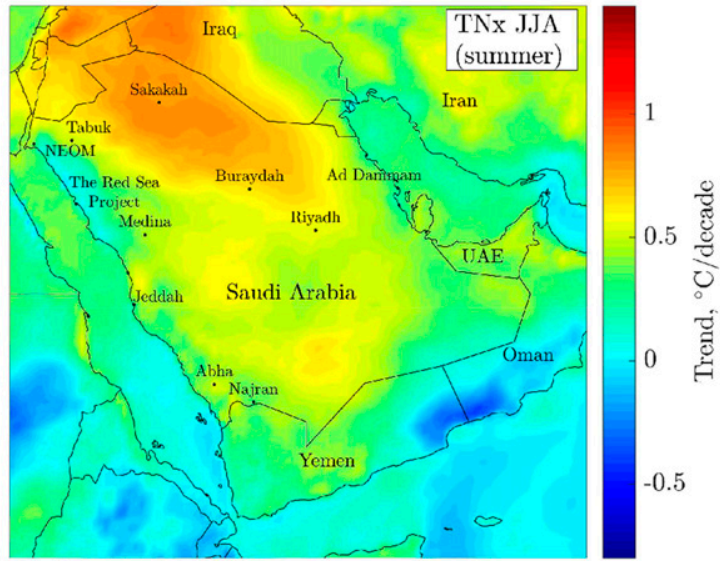

(d)

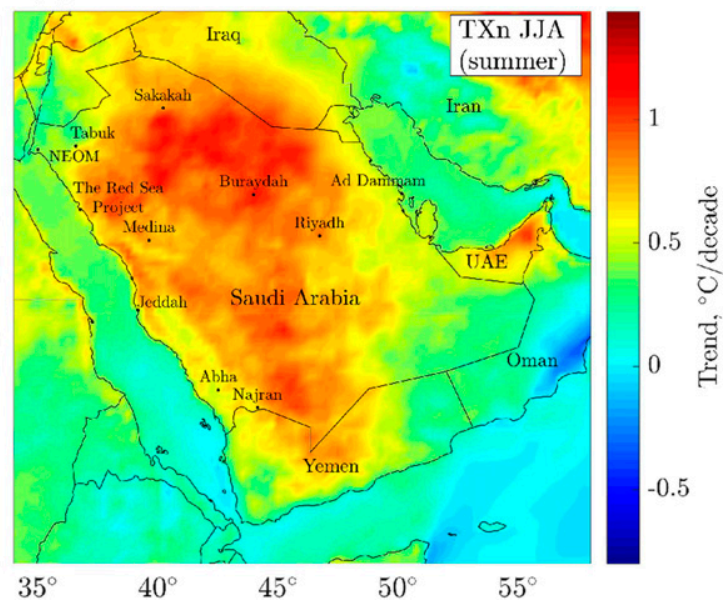

FIG. 5. As in Fig. 4, but for monthly minimum of daily maximum (TNx) and monthly maximum of daily minimum (TXn) temperature change.

analogous trend is opposite for TXn: the increase is along the Red Sea (warm nights became warmer) while the Persian Gulf coast is less affected.

Figures 6 and 7 depict how temperature extremes change over time for two representative cities: Jidda, which represents the Red Sea coastal region, and Riyadh, which represents the inland desert locations. In Riyadh, the change in average monthly minimum temperature since 1979 is about $3^{\circ} \mathrm{C}$ and almost $4^{\circ} \mathrm{C}$ for summer only. Change in average monthly maximum is about $2^{\circ} \mathrm{C}$ over the past 41 years. In Jidda, there is no clear difference between maximum and minimum temperature trends. However, it is obvious that summer extremes are increasing more rapidly. Change in both average monthly maximum and minimum temperatures in summer is about $2^{\circ} \mathrm{C}$, as compared with $1.5^{\circ} \mathrm{C}$ for the whole year. The ERA5 reference location for Jidda was chosen in direct proximity to the sea. If a location is set few kilometers inland, the result may differ and show more articulated trends, because water bodies smooth effects of extreme temperatures.

The next group of temperature indicators is based on percentiles and describes extremes in relation to a base-period "norm." The ratio of warm days in a year (TX90p; see its definition in Table 3 in section 7 of the online supplemental material) is increasing faster during summer, and the difference is clearer in inland locations (Fig. 7). In contrast, the share of cold days (TX10p) has drastically decreased since 2000. Six warm or cold days in a row constitute a heat wave or cold wave, respectively. A rapid increase of warm days led to an exponential increase in the overall duration of heat waves [warm spell duration index (WSDI)], both in Jidda and Riyadh, whereas the total duration of cold waves [cold spell duration index (CSDI)] has been rapidly decreasing. Presently, it is more common to encounter years with no cold wave, whereas years without a heat wave are extremely rare.

Another way to describe a changing climate is to count the number of days per year when a certain temperature threshold is reached. We introduce a parameter "hot days" (HD). This is an annual count of days when $T_{\max }$ reaches $37.8^{\circ} \mathrm{C}$ (or $100^{\circ} \mathrm{F}$ ). $100^{\circ} \mathrm{F}$ is a common threshold in literature defining very hot conditions (NOAA NWS 2020b; Holmes 2020; currentresults.com 2020). The map of the average value of this parameter across the kingdom is shown in Fig. 8a. The highest number of hot days is 
(a)

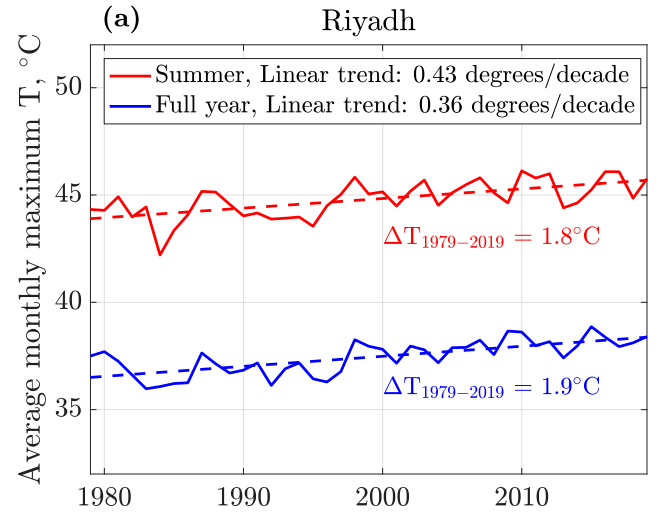

(c)

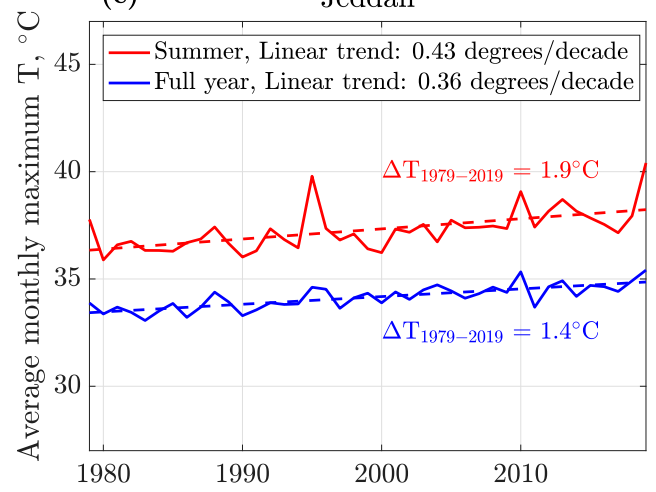

(b)

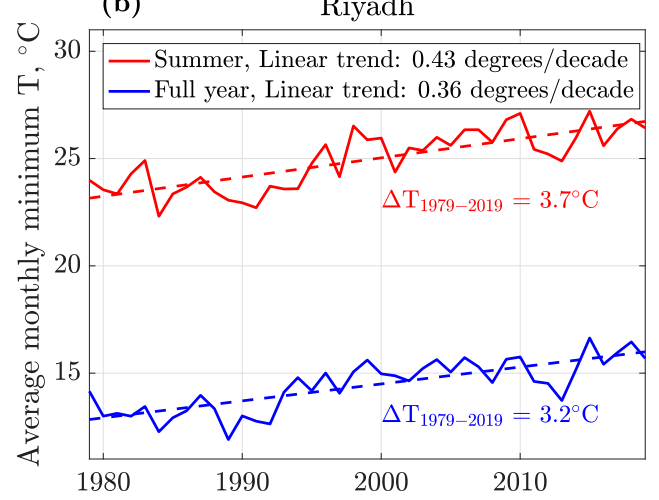

(d)

Jeddah

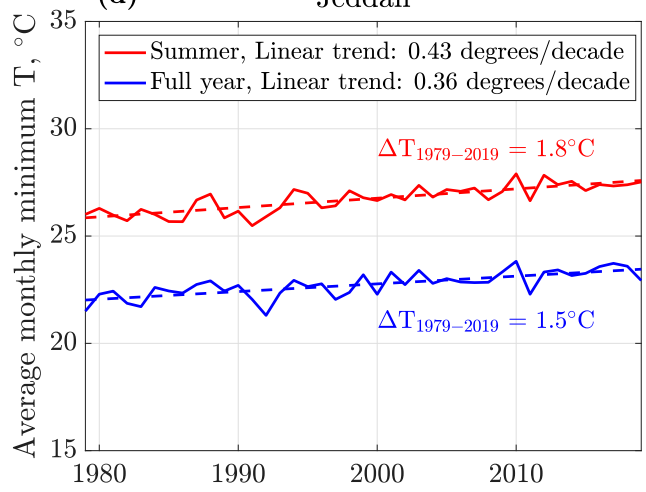

FIG. 6. Trend in yearly mean values of (left) TXx and (right) TNn temperatures for (a),(b) Riyadh and (c),(d) Jidda.

observed in the southeast of the country (the Empty Quarter desert). The desert's name reflects well the observed results, because such a harsh environment does not allow people to settle down. Among the populated areas with a high number of hot days per year, Mecca stands out. Figure $8 \mathrm{~b}$ shows the change in the HD parameter over the last 41 years on a country scale. The southeast is not showing a significant change in the trend, because the number of HD per year is already very high there. Conversely, this parameter increases very fast in the areas with less severe climate, such as the capital Sakākah and the entire Al Jawf province, which are well known for their oases and agricultural activities. The fact that the increase in the number of HD does not impact the area along the Red Sea coast stretching from NEOM down south until the Red Sea Project is noteworthy. The trend of change in the number of HD per year across the selected cities is shown in Fig. 9. For example, during the past four decades, Mecca has added an additional 50 days in a year, during which the recorded temperatures exceeded $37.8^{\circ} \mathrm{C}\left(100^{\circ} \mathrm{F}\right)$. In case the present trend continues, in a few decades many parts of Saudi Arabia will experience the same number of HD per year as the desolate Empty Quarter experiences today.

The number of summer days (SU) per year from the ETCCDI classification is similar to the number of hot days; SU is annual count of days with daily maximum temperatures reaching $25^{\circ} \mathrm{C}$.
However, this index has little practical significance for Saudi Arabia because a major part of the country's territory commonly experiences $25^{\circ} \mathrm{C}$ daily maximum temperatures. Its application is useful only for a limited number of mountain cities, where daily maximum temperatures rarely reach high values. For cities such as Abha, Taif, and Al Bahah we estimated SU index instead of hot days. The third threshold-based parameter we studied is the number of tropical nights (annual count of days with daily minimum exceeding $20^{\circ} \mathrm{C}$ ).

To summarize, the study of climate trends reveals significant increases of the mean annual and summer temperatures at the 99\% confidence level (CL) in all 20 key cities we studied. As for the temperature extremes, all locations saw statistically significant trends (99\% CL) in the number of summer days (SU, where applicable), the number of tropical nights (TR), the monthly minimum of daily maximum (TNx), and the monthly minimum of daily minimum (TNn). Warm nights (TN90p) show a positive trend, and cold nights (TN10p), a negative trend. Noteworthy, in many locations, the trend in warm days, warm nights, and annual duration of heat waves was exponential rather than linear. Positive trends in hot days (HD), monthly maximum of daily maximum (TXx), warm days TX90p, and negative trend in cold days (TN10p) were statistically significant at the $99 \% \mathrm{CL}$ in all locations, except for NEOM and the Red Sea Project. Detailed information on the 
Riyadh (a-d)

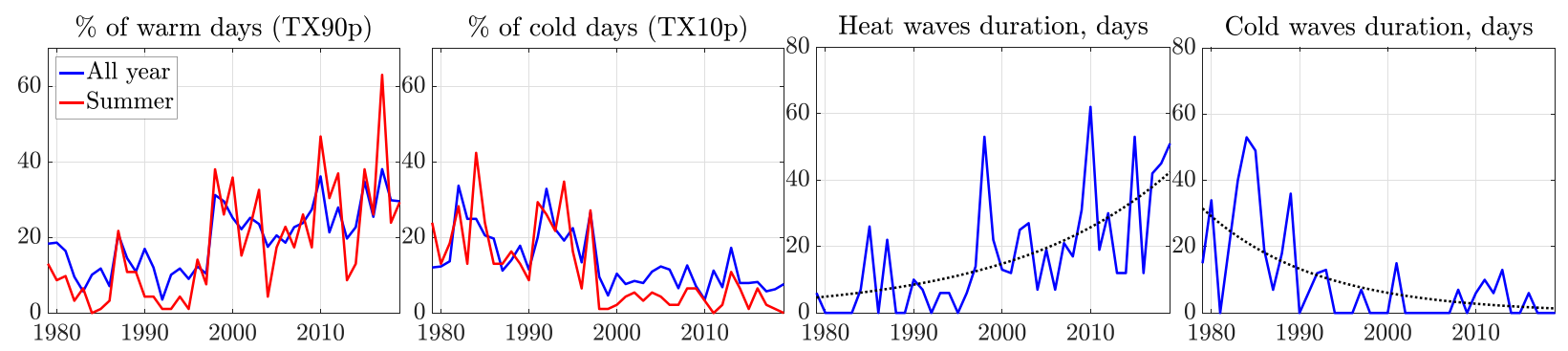

(a)

(b)

(c)

(d)

Jeddah (e-h)

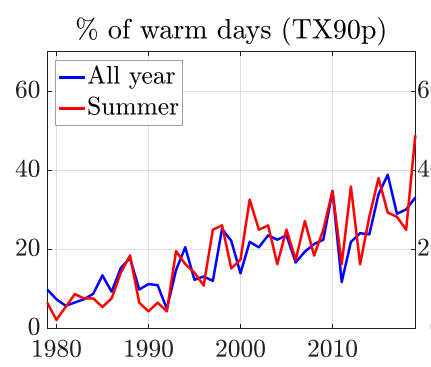

(e)

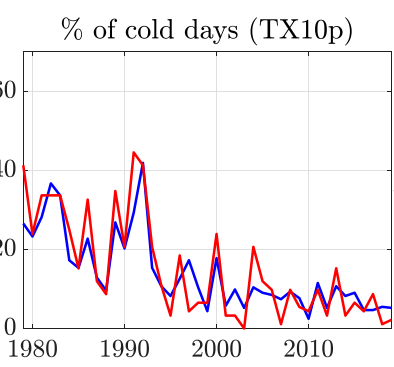

(f)

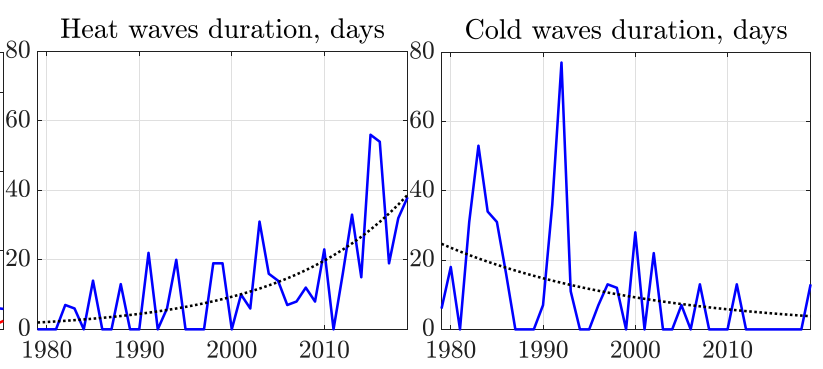

(g)

(h)

FIG. 7. Change in extreme temperature indices over the 1979-2019 period for (a)-(d) Riyadh and (e)-(h) Jidda. TX90p and TX10p stand for the percentage of warm and cold days in a year (blue) and summer (red), respectively. Total duration of heat and cold waves across a year are WSDI and CSDI, respectively. The dotted line represents an exponential model fit.

climate indicator trends for all considered cities can be found in Table 4 in section 7 of the online supplemental material.

\section{b. Dewpoint temperature and thermal comfort indicators}

Dewpoint temperature, a humidity-related parameter, has gone up very fast over the kingdom territory. In some places, the change in average summer dewpoint temperature since 1979 exceeds $6^{\circ} \mathrm{C}$. The most affected areas are the Persian Gulf coast, northeastern regions, and the central part (Fig. 10). Average summer heat index, being a function of both temperature and humidity, is increasing far more rapidly than temperature (Fig. 11; also section 6 of the online supplemental material). This result indicates that exposure of the population to thermal stress has grown markedly.

The effect of heat index on public health is divided into four categories (Table 2). In Saudi Arabia, days with "extreme (a)

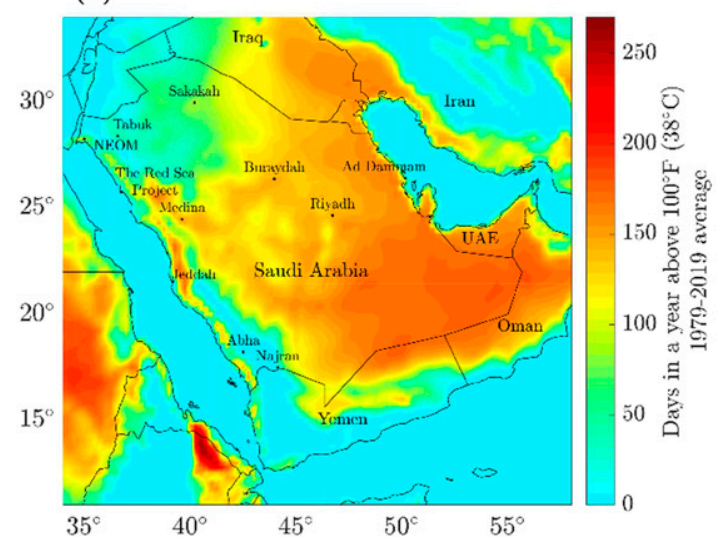

(b)

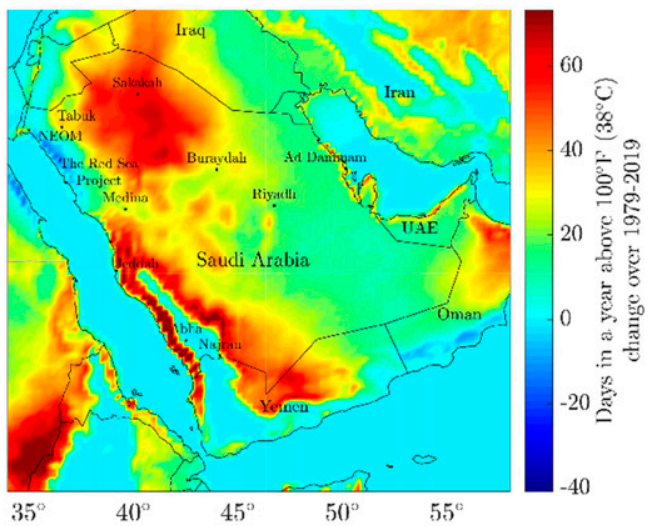

FIG. 8. (a) Average number of hot days in a year and (b) change in the number of hot days over 1979-2019 based on linear trend. These are the days with maximum temperature exceeding $100^{\circ} \mathrm{F}\left(37.8^{\circ} \mathrm{C}\right)$. 


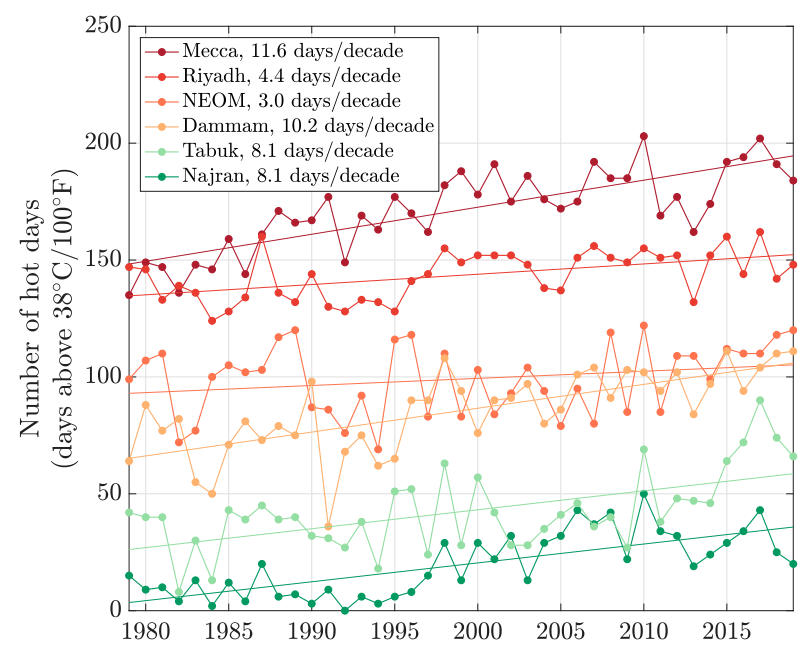

FIG. 9. Change in the number of hot days in a year over 19792019 and linear trends. These are days with maximum temperature exceeding $100^{\circ} \mathrm{F}\left(37.8^{\circ} \mathrm{C}\right)$.

danger" conditions are already present, although rare. For example, across the Persian Gulf coast, these conditions are recorded a few times per year. Days with danger conditions are far more frequent, and their occurrence since 1979 has broadened significantly (Fig. 12). Heat poses greater risk for people in coastal cities than those who are inland. The universal thermal comfort index has also increased over the past four decades, but the magnitude of change is less than that of the heat index (Fig. 13). Both indicators are similar in that they portray apparent temperature. However, the methods of their calculation are different, explaining the discrepancies in results. What correlates in both indices is the general pattern of changes: the highest trends are observed in the north next to Iraq border, in the Persian Gulf coastal areas, and in the south in the western part of Empty Quarter desert. Narrow areas between the central part of the Red Sea and elevated mountains are also greatly affected.
Among the 20 studied cities, all saw statistically significant (99\% CL) increase in summer and year-round UTCI and heat index estimated using the two best methods [NWS and Schoen (2005)]. The highest trends in thermal comfort parameters are observed in eastern province cities, Ad Dammām, Dhahran, and Hafar Al-Batin. The exceptions are Abha and Khamīs Mushayt, where heat index calculated using the NWS method did not increase (95\% CL). Year-round and summer values of dewpoint temperature increased significantly (99\% CL) in the majority of cities. However, in Abha, Khamīs Mushayt, and Medina their trends are insignificant at the 95\% CL.

\section{c. Discussion of our results in view of the previous studies}

An overview of some of the findings from the past studies and a comparison with the present study are listed below and sorted by year of publication. We limited our comparison only to those studies that have been published after 2010. It is important to highlight that the results of the previous studies in many cases do not agree with each other. For example, some publications report higher warming trends in summer months rather than winter (ElNesr et al. 2010; Rehman and AlHadhrami 2012; Almazroui et al. 2012a), but others show that summer warming is less significant (AlSarmi and Washington 2011). Some authors argue that minimum temperatures are warming faster than maximum (AlSarmi and Washington 2011), while others show the opposite (Almazroui et al. 2012b). The results of our study that relies on the high-quality reanalysis data significantly improve the understanding of historical climate change in the kingdom.

ElNesr et al. (2010) studied the mean monthly and annual temperatures for 1980-2008, using data from 29 weather stations. In general, our results when compared with their work indicate stronger heating trends, in both significance and value. For example, while ElNesr et al. observed negative trends in many locations, particularly for winter months, our results reveal no negative trends. This indicates that as time progresses, climate change is becoming clearer and its effects more significant. (a)

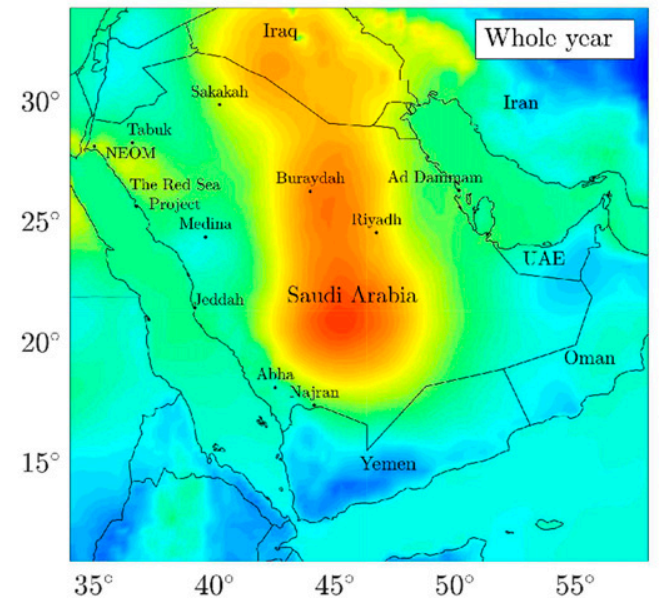

(b)

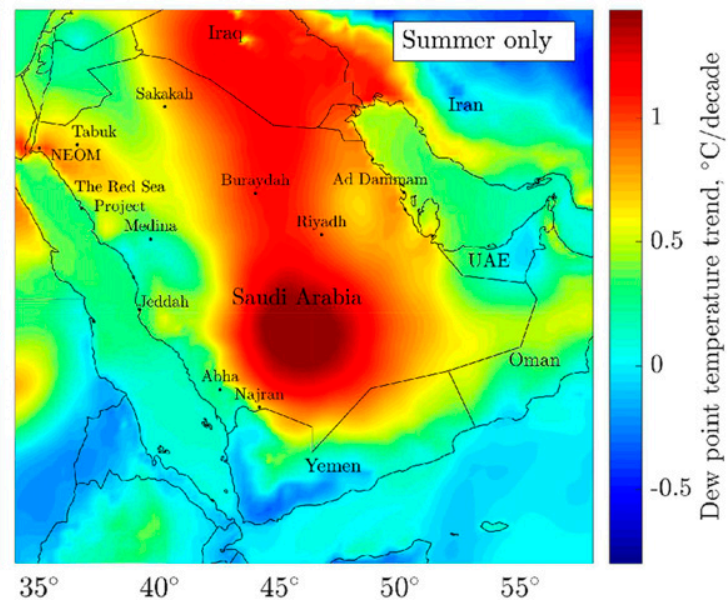

FIG. 10. Linear trends in (a) annual and (b) summer mean dewpoint temperature for the 1979-2019 period. 
(a)

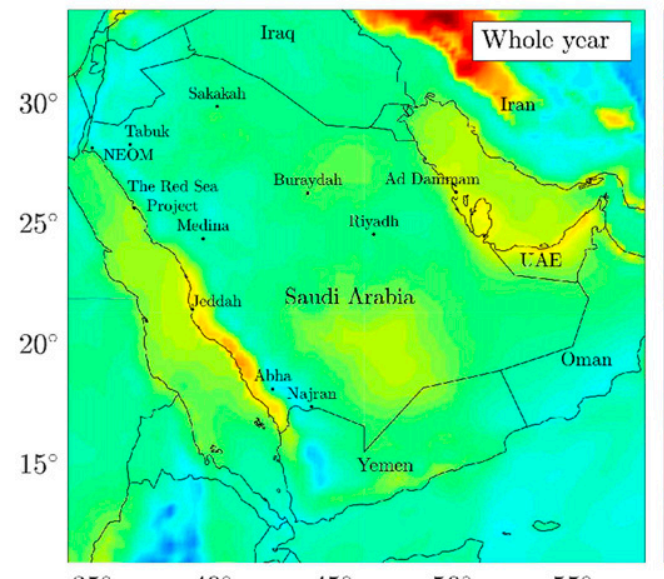

$35^{\mathrm{c}}$ $40^{\circ}$ $45^{\circ}$

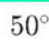

$55^{\circ}$ (b)

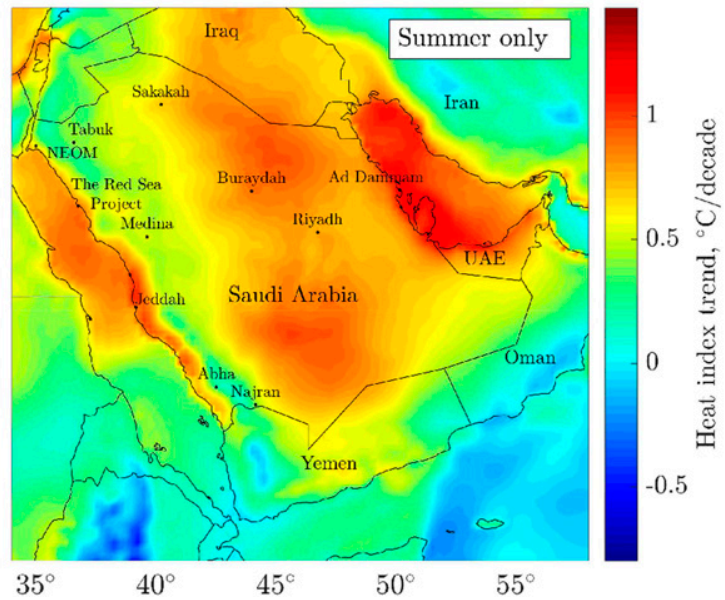

FIG. 11. Linear trends in in (a) annual and (b) summer mean heat index calculated using the NWS algorithm for the 1979-2019 period.

With respect to seasonal warming, the results of both studies agree. August was reported by ElNesr et al. to be the fastest-warming month, followed by September, October, June, and May, which is congruent with our findings. As for regional warming, ElNesr et al. showed that temperature in the southern parts of Saudi Arabia is increasing at a higher rate relative to the northern parts, with Najran, Khamīs Mushayt, and Abha having the fastest rates of temperature increase. In contrast, our spatial map shows that the north is far more impacted by rising temperatures than the south.

Rehman and Al-Hadhrami (2012) conducted an analysis of extreme temperature trends in Jidda for the period 1970-2006. Although there is general agreement of the trends observed by Rehman and Hadrami, and the present study (e.g., summer temperatures increase faster), our study that includes more recent years reveals higher warming trends. In addition, while there were negative trends observed for the specific Jidda temperature characteristics by Rehman and Hadrami over 1970-2006 (mean September-January temperatures; hot nights), these trends no longer exist during the 1979-2019 period.

TABLE 2. The effect of heat index on public health. Exposure to full sunshine can increase heat index values by up to $8^{\circ} \mathrm{C}$ (Wikipedia 2020; NOAA NWS 2020a).

\begin{tabular}{|c|c|c|}
\hline $\begin{array}{l}\text { Heat } \\
\text { index }\end{array}$ & Category & Dangers \\
\hline $26^{\circ}-32^{\circ} \mathrm{C}$ & Caution & $\begin{array}{l}\text { Fatigue is possible with prolonged } \\
\text { exposure and activity; continuing } \\
\text { activity could result in heat } \\
\text { cramps }\end{array}$ \\
\hline $32^{\circ}-41^{\circ} \mathrm{C}$ & Extreme caution & $\begin{array}{l}\text { Heat cramps and heat exhaustion } \\
\text { are possible; continuing activity } \\
\text { could result in heat stroke }\end{array}$ \\
\hline $41^{\circ}-54^{\circ} \mathrm{C}$ & Danger & $\begin{array}{l}\text { Heat cramps and heat exhaustion } \\
\text { are likely; heat stroke is probable } \\
\text { with continued activity }\end{array}$ \\
\hline Over $54^{\circ} \mathrm{C}$ & Extreme danger & Heat stroke is imminent \\
\hline
\end{tabular}

AlSarmi and Washington (2011) examined climate trends for the Arabian Peninsula using data from 21 stations, including five in Saudi Arabia. The study period was 1980-2008, except for the Saudi Arabian stations (1985-2008). With regard to Khamis Mushayt, the results show an increase of mean annual temperature at the rate of $0.60^{\circ} \mathrm{C} \mathrm{decade}^{-1}$ and a decrease of mean annual maximum temperature at the rate of $0.40^{\circ} \mathrm{C}$ decade ${ }^{-1}$. These do not correlate with our results, which show a positive $0.47^{\circ} \mathrm{C}$ decade $^{-1}$ trend in mean annual temperature and $0.51^{\circ} \mathrm{C}$ decade $^{-1}$ trend in mean annual maximum temperature for that city. The trends for Riyadh deviate as well. AlSarmi and Washington showed a $1.22^{\circ} \mathrm{C}$ decade $^{-1}$ rate of mean temperature increase for March-April, whereas our findings for these months are $0.72^{\circ}$ and $0.40^{\circ} \mathrm{C} \mathrm{decade}{ }^{-1}$ for March and April, respectively. On average, the Arabian Peninsula was reported to have minimal rate of mean temperature increase over July-September. This does not agree with our findings, which show that the increase of temperature is faster during the warm period. Our work corresponds to the findings of AlSarmi and Washington in that the mean annual minimum temperature trends are more coherent than those for the annual mean and annual maximum temperature and diurnal temperature range trend is negative in the Arabian Peninsula, meaning that nights are warming faster than days.

Almazroui et al. (2012b) reported the temperature change trend $0.60^{\circ} \mathrm{C}_{\text {decade }}{ }^{-1}$ over Saudi Arabia during 1978-2009, based on the statistics from 27 weather stations. This trend is similar to our estimate of $0.52^{\circ} \mathrm{C}$ decade $^{-1}$ (1979-2019). However, our study suggests that minimum temperatures in the kingdom are warming faster, and this does not agree with the results of Almazroui et al.; the trends of mean maximum and minimum temperatures were reported as $0.71^{\circ}$ and $0.48^{\circ} \mathrm{C}$ decade ${ }^{-1}$, respectively, in their publication. In a similar study by the same authors, it was shown that temperature change is more significant during the warmer June-September period (Almazroui et al. 2012a), and this finding corresponds well to our results. 


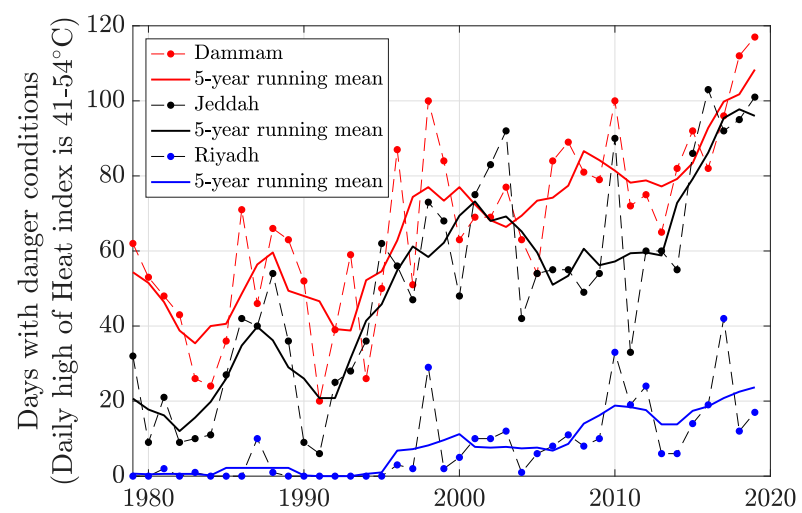

FIG. 12. Change in the number of days with danger conditions during 1979-2019 for Ad Dammām, Jidda, and Riyadh. These are days with heat index maximum in the range of $41-54^{\circ} \mathrm{C}$. The results are calculated using the NWS heat index algorithm and ERA5 historic weather data.

In their other work, Almazroui et al. (2014) went farther and focused not only on temperature change, but also on trends in extreme events for the period of 1981-2010. They obtained spatial maps of temperature extremes changes, similar to those presented in our work. However, their maps were based on the data from weather stations that are sparsely distributed in Saudi Arabia and do not adequately support drawing conclusions about specific regional changes. In comparison, the country-scale statistics and spatial maps in our work are based on data from 2785 points. When both works are compared, the change in TXx and TNx (monthly maximum and monthly minimum of daily maximum) are lower in our study and the trends for TXn and TNn (monthly maximum and minimum of daily minimum) are higher. We found no negative trends in these parameters across Saudi Arabia, whereas Almazroui et al. showed negative trends in TXn and TNn for the period 1981-2010 in many locations. There is an agreement in both works on the trends of cold nights, TN10p (decrease with a sharp decline after 2000), and warm days, TX10p (significant increase).

Tarawneh and Chowdhury (2018) analyzed historic temperature trends for Riyadh, Tabuk, and Abha representing the central, north, and southwest regions of Saudi Arabia, respectively. The results show that summer trends are greater than winter ones, which correlates with the findings of our work. Summer trend of temperature increase is reported as $0.0676^{\circ} \mathrm{C} \mathrm{yr}^{-1}$ in Riyadh and $0.0583^{\circ} \mathrm{C} \mathrm{yr}^{-1}$ in Tabuk over the $1985-2013$ period and $0.1254^{\circ} \mathrm{C} \mathrm{yr}^{-1}$ in Abha over the $1975-$ 2009 period. The results of the present study for summer temperature trends during $1979-2019$ are $0.0681^{\circ} \mathrm{C}^{-1} r^{-1}$ for Riyadh, $0.0538^{\circ} \mathrm{C} \mathrm{yr}^{-1}$ in Tabuk, and $0.0462^{\circ} \mathrm{C} \mathrm{yr}^{-1}$ in Abha. The results for Riyadh and Tabuk correspond well, whereas they deviate for Abha. The deviation can be explained by the remote location of the Abha weather station, away from the center of the city, whereas the ERA5 data point is close to the city center.

The paper by Ntoumos et al. (2020) focused on the study of temperature extremes over the Middle East and North Africa (MENA) region for the period of 1980-2018. The authors used data from 18 model results from phase 5 of the Coupled Model Intercomparison Project (CMIP5), two reanalyses (ERAInterim and MERRA-2), and observations (Berkeley Earth). ERA-Interim is the previous generation of the ECMWF reanalysis. We have used the most recent one (ERA5). Ntoumos et al. showed maps for trends in some of the extreme indices, while the statistics for all investigated parameters was averaged for the MENA domain and presented as bar graphs. Although the maps do not allow one to make specific conclusions about regional and city-scale changes over Saudi Arabia because of low resolution, the general results are consistent with ours (for the maps of trends in TXx and TNx). For the entire MENA, Ntoumos et al. reported higher warming in the warm extremes rather than cold ones. Trends in cold extremes (TNn, TXn) were reported as about $0.1^{\circ} \mathrm{C}$ decade $^{-1}$ and were insignificant. (a)

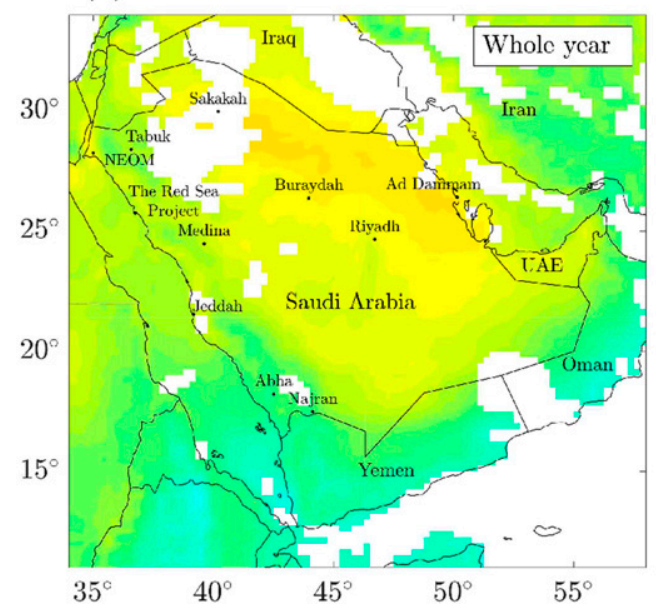

(b)

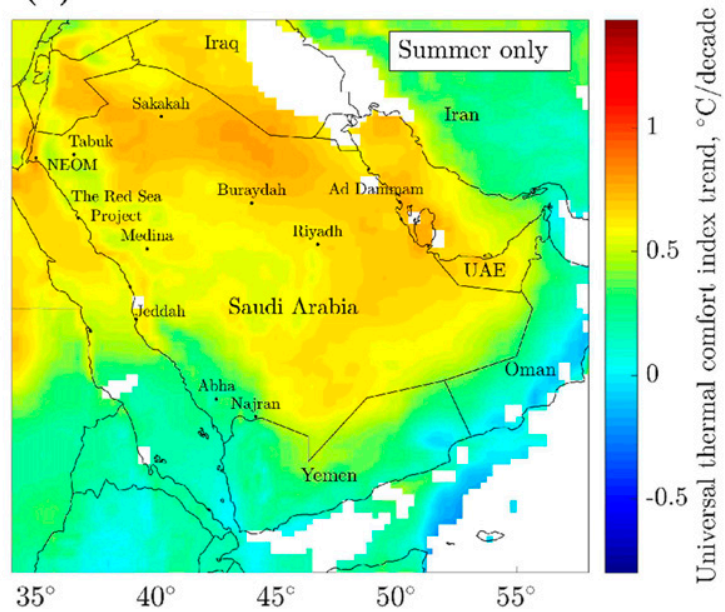

FIG. 13. Linear trends in (a) annual and (b) summer mean universal thermal comfort index for the 1979-2019 period. 
Trends in warm extremes ( $\mathrm{TXx}$ and $\mathrm{TNx}$ ) were about $0.3^{\circ} \mathrm{C}$ decade $^{-1}$. In contrast, our results for Saudi Arabia are opposite to the MENA region statistics. There are statistically significant increases in both cold and warm extremes, with a more persistent trend in cold extremes. This stresses the importance of country-scale analysis, as the specific results may differ from the broad regional ones.

Almazroui (2020a) showed the changes in temperature trends and extremes over Saudi Arabia for the period of 19782019. The results are consistent with ours in the following: minimum temperatures are increasing faster than maximum ones, DTR is decreasing, warming trends are significant for TX90p, TN90p, TX10p, and TN10p (particularly after 2000), and the number of cold days is significantly decreasing. This highlights our conclusion that the incorporation of the most recent data is very important to produce reliable results. The only incongruity is that Almazroui (2020a) report that winter warming is more pronounced than summer warming, whereas our results show the opposite. The reason for this discrepancy should be further investigated.

\section{Summary for policy makers}

There is unequivocal evidence that climate is warming in Saudi Arabia at a rate that is much faster than that for the rest of land in the Northern Hemisphere and for the planet. Extreme events are becoming more frequent and pose significant health risks to people and businesses. Tending to the essential needs of population must be at the forefront of the national climate change adaptation agenda. Foremost, stable, uninterrupted access to cooling and freshwater is essential. However, traditional supply chains have flaws, such as the heavily centralized production, which is vulnerable to a host of disruptions. Even short disruptions of electricity and freshwater supply may become dangerous or even deadly in the future.

\section{a. Faster energy transition}

Despite the successful application of recent energy price reforms and policies in Saudi Arabia (Howarth et al. 2019), energy consumption per capita is among the highest in the world. Further demand reduction via price signals, carbon tax, and consumption awareness campaigns may facilitate a transition to alternative energy sources. This transition could result in distributed generation and utility-scale renewable energy sources that have not been cost effective or feasible in the past. Grid stability with fluctuating power from renewable source will be of vital importance in Saudi Arabia. Energy storage as hydrogen and thermal storage could enhance the use of Saudi Arabia's rich renewable energy potential. Hydrogen might be also advantageous for alternative transportation, electricity generation, and various energy intensive industrial processes. Thermal power plants produce nearly all the kingdom's power [Electricity \& Cogeneration Regulatory Authority (ECRA) 2018] and must use water for cooling. This means that energy and water security go hand in hand and are equally important. Saudi Arabia is one of the most water scarce regions of the planet, and to accommodate its needs, the country relies on nonrenewable groundwater and desalination, which at present is $100 \%$ fossil powered (ECRA 2018). Water must be treated and not wasted. It can be reused for power generation and agriculture. Solar-heat desalination might help to decarbonize freshwater production and might be more appropriate in Saudi Arabia than photovoltaics that deteriorate quickly with dust agglomeration and extreme temperatures.

\section{b. Keeping cool}

It is important to diversify air-conditioning (AC) technologies. These must not be limited to traditional vapor-compression systems. Evaporative coolers and solar thermal air conditioners are examples of other types of AC that deserve attention. They are less dependent on electricity from the grid and may leverage national load variations if widely applied. They are also more resilient than conventional air conditioning systems in the face of power supply disturbances. In addition, district cooling and non-AC cooling should be better evaluated and implemented. The standards for building-envelope design must be enforced and raised, with particular attention to insolation and energy efficiency.

\section{c. Cities of the future}

New construction must be planned in accordance with climate change adaptation strategies. Our results indicate that NEOM has one of the most favorable strategic locations. The future megacity has not only a milder climate, but also stands out as a region with perhaps the lowest rate of temperature and temperature extremes increases. Application of the best construction design practices for new buildings and measures to mitigate heat island effect is necessary to ensure safety of city dwellers amid a fast-warming climate. Early planning of resource recycling-water, waste, and materials-would contribute to a decrease of primary power consumption and reduction of emissions. In addition, it will generate local supply chains and secure jobs.

\section{Conclusions}

Lack of data of sufficient spatial density and years available for analysis was the major constraint in the studies of climate change and associated weather extremes in Saudi Arabia. This issue has been addressed in the present work, enabled by release of the high-quality hourly weather parameters from ERA5 in 2019. We have analyzed the past climate change in Saudi Arabia with respect to temperature, temperature extremes, dewpoint temperature and humidity-related thermal comfort parameters, and presented detailed results for $20 \mathrm{key}$ cities. The study period of 1979-2019 includes the most recent years, and data were obtained from the state-of-the-art ECMWF ERA5 reanalysis of global climate. An important feature of our work is that summer trends were assessed separately from annual ones.

Saudi Arabia is experiencing a strong warming trend. The June-August temperatures are increasing faster than all-year ones, and nights are warming faster than days. Rapid growth in warm days has resulted in an exponential increase of heat wave duration in most of the studied cities. Coastal locations are less affected by the rise of temperature and the temperature extremes. But these areas are strongly impacted by the elevation 
of heat index. The magnitude of changes over the Persian Gulf coast is generally higher than over the Red Sea.

An in-depth overview of the date evolution of thermal comfort indicators has not been done before for Saudi Arabia. We have analyzed a novel universal thermal comfort index and traditional heat index. The study of the latter one was done using three different approaches. We have shown that the thermal comfort indicators trends over summer are higher than the trend in temperature. Simple temperature trends may mask the more significant change of apparent or perceived temperature, which is the true indicator of exposure to heat and thermal stress. For example, in Ad Dammām, summer heat index has been increasing twice as fast as temperature with an increment of $4.4^{\circ} \mathrm{C}$ since 1979 . In this context, it is worth being reminded that these changes have happened amid the planetary temperature increase of just $1^{\circ} \mathrm{C}$ since preindustrial times. Our findings and recommendations are therefore important to policy makers in the Middle East.

Acknowledgments. We acknowledge the Copernicus Climate Change Service (C3S), a part of the Copernicus Earth Observation Programme of the European Union, and the European Centre for Medium-Range Weather Forecasts (ECMWF) for providing to us the open-access, high-quality ERA5 hourly data on temperature and other weather parameters. We also thank Professor Georgiy L. Stenchikov, Dr. Sergey Osipov, and three anonymous reviewers for their helpful remarks on the paper.

Data availability statement. The 2-m temperature, 2-m dewpoint temperature (under the "ERA5 hourly data on single levels from 1979 to present" dataset; https://cds.climate. copernicus.eu/cdsapp\#!/dataset/reanalysis-era5-single-levels?tab= overview), and universal thermal comfort index (under the "Thermal comfort indices derived from ERA5 reanalysis" dataset; https://cds.climate.copernicus.eu/cdsapp\#!/dataset/derived-utcihistorical?tab=overview) data for 1979-2019 used during this study are openly available from the Copernicus Climate Data Store (https://cds.climate.copernicus.eu/cdsapp\#!/search?type= dataset; Copernicus Climate Change Service 2020a,b). Global values on temperature anomalies for 1880-2019 used during this study are openly available from the NASA Goddard Institute for Space Studies (https://data.giss.nasa.gov/gistemp/; GISTEMP Team 2020a,b; Lenssen et al. 2019).

\section{REFERENCES}

Agarwal, A. K., S. Dwivedi, and A. Ghanshyam, 2018: Summer heat: Making a consistent health impact. Indian J. Occup. Environ. Med., 22, 57-58, https://doi.org/10.4103/ijoem.IJOEM_94_17.

Alexander, L. V., and J. M. Arblaster, 2017: Historical and projected trends in temperature and precipitation extremes in Australia in observations and CMIP5. Wea. Climate Extremes, 15, 34-56, https://doi.org/10.1016/j.wace.2017.02.001.

Almazroui, M., 2013: Simulation of present and future climate of Saudi Arabia using a regional climate model (PRECIS). Int. J. Climatol., 33, 2247-2259, https://doi.org/10.1002/joc.3721. , 2020a: Changes in temperature trends and extremes over Saudi Arabia for the period 1978-2019. Adv. Meteor., 2020, 8828421, https://doi.org/10.1155/2020/8828421.
— 2020b: Summer maximum temperature over the Gulf Cooperation Council states in the twenty-first century: Multimodel simulations overview. Arab. J. Geosci., 13, 477, https://doi.org/10.1007/s12517-020-05537-x.

_- M. N. Islam, P. Jones, H. Athar, and M. A. Rahman, 2012a: Recent climate change in the Arabian Peninsula: Seasonal rainfall and temperature climatology of Saudi Arabia for 1979-2009. Atmos. Res., 111, 29-45, https://doi.org/10.1016/ j.atmosres.2012.02.013.

,,-- H. Athar, P. Jones, and M. A. Rahman, 2012b: Recent climate change in the Arabian Peninsula: Annual rainfall and temperature analysis of Saudi Arabia for 1978-2009. Int. J. Climatol., 32, 953-966, https://doi.org/10.1002/joc.3446.

,,-- R. Dambul, and P. Jones, 2014: Trends of temperature extremes in Saudi Arabia. Int. J. Climatol., 34, 808-826, https:// doi.org/10.1002/joc.3722.

— — - S. Saeed, A. K. Alkhalaf, and R. Dambul, 2017: Assessment of uncertainties in projected temperature and precipitation over the Arabian Peninsula using three categories of CMIP5 multimodel ensembles. Earth Syst. Environ., 1, 23, https://doi.org/10.1007/s41748-017-0027-5.

AlSarmi, S., and R. Washington, 2011: Recent observed climate change over the Arabian Peninsula. J. Geophys. Res., 116, D11109, https://doi.org/10.1029/2010JD015459.

Anderson, G. B., M. L. Bell, and R. D. Peng, 2013: Methods to calculate the heat index as an exposure metric in environmental health research. Environ. Health Perspect., 121, 11111119, https://doi.org/10.1289/ehp.1206273.

Bangalath, H. K., and G. Stenchikov, 2015: Role of dust direct radiative effect on the tropical rain belt over Middle East and North Africa: A high-resolution AGCM study. J. Geophys. Res., 120, 4564-4584, https://doi.org/10.1002/2015JD023122.

climdex.org, 2020: Climdex indices. Accessed 23 July 2020, https:// www.climdex.org/learn/indices.

Collins, M., and Coauthors, 2013: Long-term climate change: Projections, commitments and irreversibility. Climate Change 2013: The Physical Science Basis, T. F. Stocker et al., Eds., Cambridge University Press, 1029-1136.

Copernicus Climate Change Service, 2020a: Copernicus Climate Data Store. Accessed 23 July 2020, https://cds.climate.copernicus.eu/ \#!/home.

_ 2020b: ERA5: Fifth generation of ECMWF atmospheric reanalyses of the global climate. Climate Data Store, accessed 23 July 2020, https://cds.climate.copernicus.eu/cdsapp\#!/search? type $=$ dataset $\&$ text $=$ ERA5.

currentresults.com, 2020: Average number of hot days at US cities in summer. Current Results, accessed 23 July 2020, https:// www.currentresults.com/Weather/US/number-hot-days-citiessummer.php.

Di Cristo, R., A. Mazzarella, and R. Viola, 2007: An analysis of heat index over Naples (southern Italy) in the context of European heat wave of 2003. Nat. Hazards, 40, 373-379, https://doi.org/10.1007/s11069-006-0033-7.

Di Napoli, C., C. Barnard, C. Prudhomme, H. L. Cloke, and F. Pappenberger, 2020: ERA5-HEAT: A global gridded historical dataset of human thermal comfort indices from climate reanalysis. Geosci. Data J., 8, 2-10, https://doi.org/10.1002/gdj3.102.

Dogar, M. M., G. Stenchikov, S. Osipov, B. Wyman, and M. Zhao, 2017: Sensitivity of the regional climate in the Middle East and North Africa to volcanic perturbations. J. Geophys. Res. Atmos., 122, 7922-7948, https://doi.org/10.1002/2017JD026783.

Driouech, F., K. ElRhaz, W. Moufouma-Okia, K. Arjdal, and S. Balhane, 2020: Assessing future changes of climate extreme 
events in the CORDEX-MENA region using regional climate model ALADIN-Climate. Earth Syst. Environ., 4, 477-492, https://doi.org/10.1007/s41748-020-00169-3.

ECMWF, 2020: User guide: Thermal comfort indices derived from ERA5 reanalysis. Copernicus Climate Data Store Doc., 6 pp., https://datastore.copernicus-climate.eu/documents/utci/ UTCIMRTdatabase_UserGuide.pdf.

ECRA, 2018: Annual statistical booklet for electricity \& seawater desalination industries. Electricity \& Cogeneration Regulatory Authority Doc., 164 pp., https://ecra.gov.sa/en-us/MediaCenter/ DocLib2/Lists/SubCategory_Library/Statistical_Booklet2018.pdf.

El Morjani, Z. E. A., S. Ebener, J. Boos, E. A. Ghaffar, and A. Musani, 2007: Modelling the spatial distribution of five natural hazards in the context of the WHO/EMRO Atlas of Disaster Risk as a step towards the reduction of the health impact related to disasters. Int. J. Health Geogr., 6, 8, https:// doi.org/10.1186/1476-072X-6-8.

EINesr, M. N., M. M. Abu-Zreig, and A. A. Alazba, 2010: Temperature trends and distribution in the Arabian Peninsula. Amer. J. Environ. Sci., 6, 191-203, https://doi.org/10.3844/ajessp.2010.191.203.

El-Samra, R., E. Bou-Zeid, H. K. Bangalath, G. Stenchikov, and M. El-Fadel, 2017: Future intensification of hydro-meteorological extremes: Downscaling using the weather research and forecasting model. Climate Dyn., 49, 3765-3785, https://doi.org/10.1007/ s00382-017-3542-z.

Enerdata, 2020: EnerDemand: The global efficiency and demand database. Accessed 23 July 2020, https://www.enerdata.net/ research/world-energy-efficiency-demand-database.html.

Epstein, P. R., 1999: Climate and health. Science, 285, 347-348, https://doi.org/10.1126/science.285.5426.347.

ETCCDI, 2020: Climate change indices. Accessed 23 July 2020, http://etccdi.pacificclimate.org/indices.shtml.

Fandoeva, M., T. Kiseliova, and A. Sikharulidze, 2009: Investigation of the heat index in Georgia based on the most typical fuzzy expected values. Computing and Computational Intelligence: Proc. Third Int. Conf. on European Computing, Stevens Point, WI, WSEAS, 302-308, http://www.wseas.us/e-library/conferences/ 2009/georgia/CCI/CCI48.pdf.

Gasparrini, A., and B. Armstrong, 2011: The impact of heat waves on mortality. Epidemiology, 22, 68-73, https://doi.org/10.1097/ EDE.0b013e3181fdcd99.

GISTEMP Team, 2020a: Combined land-surface air and sea-surface water temperature anomalies. GISS Surface Temperature Analysis, version 4, NASA Goddard Institute for Space Studies, accessed 23 July 2020, https://data.giss.nasa.gov/gistemp. , 2020b: Surface air temperature (no ocean data), 250km smoothing. GISS Surface Temperature Analysis, version 4, NASA Goddard Institute for Space Studies, accessed 23 July 2020, https:// data.giss.nasa.gov/pub/gistemp/gistemp250_GHCNv4.nc.gz.

Gronlund, C. J., K. P. Sullivan, Y. Kefelegn, L. Cameron, and M. S. O'Neill, 2018: Climate change and temperature extremes: A review of heat- and cold-related morbidity and mortality concerns of municipalities. Maturitas, 114, 54-59, https:// doi.org/10.1016/j.maturitas.2018.06.002.

Hennermann, K., 2020: ERA5: What is the spatial reference. ECMWF, accessed 23 July 2020, https://confluence.ecmwf.int/ display/CKB/ERA5\%3A + What + is + the + spatial+reference.

Hersbach, H., 2017: ERA5: The new reanalysis of weather and climate data. ECMWF, http://www.ecmwf.int/en/about/mediacentre/science-blog/2017/era5-new-reanalysis-weather-andclimate-data.

Holmes, J., 2020: If you like 100-degree days, you're going to love climate change. Esquire, 16 July 2019, https://www.esquire.com/ news-politics/a28408603/climate-change-100-degree-days-heatindex-study/.

Howarth, N., A. Lanza, and T. Alshehri, 2019: Saudi Arabia's 2018 $\mathrm{CO}_{2}$ emissions fall faster than expected. KAPSARC, $16 \mathrm{pp}$., https://www.kapsarc.org/research/publications/saudi-arabias2018-co2-emissions-fall-faster-than-expected/.

—, N. Odnoletkova, T. Alshehri, A. Almadani, A. Lanza, and T. Patzek, 2020: Staying cool in a warming climate: Temperature, electricity and air conditioning in Saudi Arabia. Climate, 8, 4, https://doi.org/10.3390/cli8010004.

Huang, D., Y. Qian, and J. Zhu, 2010: Trends of temperature extremes in China and their relationship with global temperature anomalies. Adv. Atmos. Sci., 27, 937-946, https://doi.org/ 10.1007/s00376-009-9085-4.

IPCC, 2013: Climate Change 2013: The Physical Science Basis. Cambridge University Press, 1535 pp., https://doi.org/10.1017/ CBO9781107415324.

Jendritzky, G., R. de Dear, and G. Havenith, 2012: UTCI-Why another thermal index? Int. J. Biometeor., 56, 421-428, https:// doi.org/10.1007/s00484-011-0513-7.

Johnson, T., and T. Long, 2005: Determining the frequency of open windows in residences: A pilot study in Durham, North Carolina during varying temperature conditions. J. Exposure Sci. Environ. Epidemiol., 15, 329-349, https://doi.org/10.1038/ sj.jea.7500409.

Karl, T. R., N. Nicholls, and A. Ghazi, 1999: CLIVAR/GCOS/ WMO Workshop on Indices and Indicators for Climate Extremes workshop summary. Weather and Climate Extremes, T. R. Karl, N. Nicholls, and A. Ghazi, Eds., Springer, 3-7.

Kompas, T., V. H. Pham, and T. N. Che, 2018: The effects of climate change on GDP by country and the global economic gains from complying with the Paris climate accord. Earth's Future, 6, 1153-1173, https://doi.org/10.1029/2018EF000922.

Lapillonne, B., 2019: Future of air-conditioning: Executive brief-September 2019. ENERDATA Doc., 7 pp., https:// d1owejb4br3112.cloudfront.net/publications/executive-briefing/ future-air-conditioning.pdf.

Lelieveld, J., Y. Proestos, P. Hadjinicolaou, M. Tanarhte, E. Tyrlis, and G. Zittis, 2016: Strongly increasing heat extremes in the Middle East and North Africa (MENA) in the 21st century. Climatic Change, 137, 245-260, https://doi.org/10.1007/s10584016-1665-6.

Lenssen, N. J., G. A. Schmidt, J. E. Hansen, M. J. Menne, A. Persin, R. Ruedy, and D. Zyss, 2019: Improvements in the GISTEMP uncertainty model. J. Geophys. Res. Atmos., 124, 6307-6326, https://doi.org/10.1029/2018JD029522.

Li, D., J. Yuan, and R. E. Kopp, 2020: Escalating global exposure to compound heat-humidity extremes with warming. Environ. Res. Lett., 15, 064003, https://doi.org/10.1088/1748-9326/ab7d04.

McMichael, A. J., D. H. Campbell-Lendrum, C. F. Corvalán, K. L. Ebi, A. Githeko, J. D. Scheraga, and A. Woodward, 2003: Climate Change and Human Health: Risks and Responses. World Health Organization, 322 pp.

NASA Goddard Space Flight Center, 2020: Characterizing extremes for the recent past over the Americas. Global Modeling and Assimilation Office, accessed 23 July 2020, gmao.gsfc.nasa.gov/ research/subseasonal/atlas/Extremes.html.

NOAA NCEI, 2020: El Niño/Southern Oscillation-Annual 2008. NOAA, accessed 23 July 2020, https://www.ncdc.noaa.gov/ sotc/enso/200813.

NOAA NWS, 2020a: Heat index calculator. Weather Prediction Center, accessed 23 July 2020, https://www.wpc.ncep.noaa.gov/ $\mathrm{html} /$ heatindex.shtml. 
— 2020b: Number of days 100 or more degrees. NWS, accessed 23 July 2020, https://www.weather.gov/tsa/climo_100Days.

Ntoumos, A., P. Hadjinicolaou, G. Zittis, and J. Lelieveld, 2020: Updated assessment of temperature extremes over the Middle East-North Africa (MENA) region from observational and CMIP5 data. Atmosphere, 11, 813, https://doi.org/10.3390/ atmos11080813.

Oka, M., 2011: The influence of urban street characteristics on pedestrian heat comfort levels in Philadelphia. Trans. GIS, 15, 109-123, https://doi.org/10.1111/j.1467-9671.2010.01245.x.

Osipov, S., and G. Stenchikov, 2017: Regional effects of the Mount Pinatubo eruption on the Middle East and the Red Sea. J. Geophys. Res. Oceans, 122, 8894-8912, https://doi.org/ 10.1002/2017JC013182.

— Middle East climate and the Red Sea. J. Geophys. Res. Oceans, 123, 1032-1047, https://doi.org/10.1002/2017JC013335.

Parry, M., and M. L. Swaminathan, 1993: Effects of climate change on food production. Confronting Climate Change: Risks, Implications and Responses, I. M. Mintzer, Ed., Cambridge University Press, 113-126, https://doi.org/10.1017/CBO9780511608292.009.

Patz, J. A., D. Campbell-Lendrum, T. Holloway, and J. A. Foley, 2005: Impact of regional climate change on human health. Nature, 438, 310-317, https://doi.org/10.1038/nature04188.

Peterson, T., 2005: Climate change indices. WMO Bull., 54, 8386.

— C. Folland, G. Gruza, W. Hogg, A. Mokssit, and N. Plummer, 2001: Report on the activities of the working group on climate change detection and related rapporteurs: 1998-2001. WMO Tech Doc. WMO/TD 1071, WCDMP 47, 143 pp.

Predybaylo, E., G. L. Stenchikov, A. T. Wittenberg, and F. Zeng, 2017: Impacts of a Pinatubo-size volcanic eruption on ENSO. J. Geophys. Res., 122, 925-947, https://doi.org/ 10.1002/2016JD025796.

Raj, J., H. K. Bangalath, and G. Stenchikov, 2019: West African monsoon: Current state and future projections in a highresolution AGCM. Climate Dyn., 52, 6441-6461, https:// doi.org/10.1007/s00382-018-4522-7.

Rajib, M. A., M. R. Mortuza, S. Selmi, A. K. Ankur, and M. M. Rahman, 2011: Increase of heat index over Bangladesh: Impact of climate change. World Acad. Sci. Eng. Technol., 58, 402-405, doi.org/10.5281/zenodo.1082207.
Rehman, S., and L. M. Al-Hadhrami, 2012: Extreme temperature trends on the west coast of Saudi Arabia. Atmos. Climate Sci., 2, 351-361, http://dx.doi.org/10.4236/acs.2012.23031.

Schoen, C., 2005: A new empirical model of the temperaturehumidity index. J. Appl. Meteor., 44, 1413-1420, https:// doi.org/10.1175/JAM2285.1.

Steadman, R. G., 1979a: The assessment of sultriness. Part I: A temperature-humidity index based on human physiology and clothing science. J. Appl. Meteor., 18, 861-873, https://doi.org/ 10.1175/1520-0450(1979)018<0861:TAOSPI >2.0.CO;2.

- 1979b: The assessment of sultriness. Part II: Effects of wind, extra radiation and barometric pressure on apparent temperature. J. Appl. Meteor., 18, 874-885, https://doi.org/10.1175/ 1520-0450(1979)018<0874:TAOSPI > 2.0.CO;2.

- 1984: A universal scale of apparent temperature. J. Climate Appl. Meteor., 23, 1674-1687, https://doi.org/10.1175/15200450(1984)023<1674:AUSOAT>2.0.CO;2.

Tarawneh, Q. Y., and S. Chowdhury, 2018: Trends of climate change in Saudi Arabia: Implications on water resources. Climate, 6, 8, https://doi.org/10.3390/cli6010008.

Thorne, P., and Coauthors, 2016: Reassessing changes in diurnal temperature range: Intercomparison and evaluation of existing global data set estimates. J. Geophys. Res. Atmos., 121, 5138-5158, https://doi.org/10.1002/2015JD024584.

Thow, A., and M. De Blois, 2008: Climate change and human vulnerability: Mapping emerging trends and risk hotspots for humanitarian actors. Maplecroft Rep., 30 pp., https://reliefweb.int/sites/reliefweb.int/ files/resources/E5549F80673D1E38C12574B0004B698F-care_ mar2008.pdf.

Vose, R. S., D. R. Easterling, and B. Gleason, 2005: Maximum and minimum temperature trends for the globe: An update through 2004. Geophys. Res. Lett., 32, L23822, https://doi.org/ 10.1029/2005GL024379.

Wikipedia, 2020: Heat index. Accessed 23 July 2020, https:// en.wikipedia.org/wiki/Heat_index.

You, Q., S. Kang, N. Pepin, and Y. Yan, 2008: Relationship between trends in temperature extremes and elevation in the eastern and central Tibetan Plateau, 1961-2005. Geophys. Res. Lett., 35, L04704, https://doi.org/10.1029/2007GL032669.

Zhang, Y., I. Held, and S. Fueglistaler, 2021: Projections of tropical heat stress constrained by atmospheric dynamics. Nat. Geosci., 14, 133-137, https://doi.org/10.1038/s41561-021-00695-3. 